\title{
Molecular Modeling and Synthesis of New Heterocyclic Compounds Containing Pyrazole as Anticancer Drugs
}

\author{
Fiby N. Takla ${ }^{*}$, Abdelbasset A. Farahat ${ }^{2}$, Magda A.-A. El-Sayed², Magda N. A. Nasr ${ }^{2}$ \\ ${ }^{1}$ Organic Chemistry Department, Delta School of Pharmacy, Gamasa, Egypt \\ ${ }^{2}$ Organic Chemistry Department, Mansoura School of Pharmacy, Mansoura, Egypt \\ Email: *drfiby_87@yahoo.com
}

How to cite this paper: Takla, F.N., Farahat, A.A., El-Sayed, M.A.-A. and Nasr, M.N.A. (2017) Molecular Modeling and Synthesis of New Heterocyclic Compounds Containing Pyrazole as Anticancer Drugs. International Journal of Organic Chemistry, 7, 369-388.

https://doi.org/10.4236/ijoc.2017.74030

Received: August 23, 2017

Accepted: December 12, 2017

Published: December 15, 2017

Copyright $\odot 2017$ by authors and Scientific Research Publishing Inc. This work is licensed under the Creative Commons Attribution International License (CC BY 4.0).

http://creativecommons.org/licenses/by/4.0/

\begin{abstract}
Several modifications in CA-4 were reported in literature for the development of various tubulin inhibitors. In our study, twenty-two newly synthesized heterocyclic derivatives of Combretastatin A-4 (CA-4) have been tested for their cytotoxic effect on four different types of cells with malignant behavior using CA-4 as a positive control. Compounds $5 \mathrm{~b}, 15$ and 16 showed the foremost potent antiproliferative activities as compared to CA-4 with IC50 starting from 6.9 to $13.7 \mu \mathrm{M}$. Molecular docking was performed with the crystal structure of tubulin employing a potent tubulin inhibitor CA-4 as a parent molecule. Molecular study advised that $5 \mathrm{~b}, 15,16$ and 17 are promising tubulin inhibitors.
\end{abstract}

\section{Keywords}

Tubulin, CA-4, Anticancer, Pyrazole, Molecular Modeling

\section{Introduction}

Microtubule-targeting agents are used clinically as antitumor drugs. Their anticancer activity is commonly due to tubulin inhibition. They prevent the formation of microtubule, thus affecting cellular replication and shape [1]. In general, antitubulin agents bind with five totally different binding pockets on the $\beta$-tubulin subunit [2]. Agents that strongly react with colchicine binding site induce depolymerization of tubulin, therefore they inhibit tubulin action [3] (Figure 1(a)). This study will focus on agents that target colchicine-binding site [4].

The natural product CA-4 that is under investigation as it has a strong affinity to colchicine binding site, and therefore a strong tubulin inhibitor. Thus, we use 
<smiles>COC1=C(OC)C2CC=CC(O)C(=O)C=C2C2=C1C(CCNC(C)=O)CCCC2</smiles>

Colchicine<smiles>COc1cc([C@H]2c3cc4c(cc3[C@@H](O)C3COC(=O)[C@H]32)OCO4)cc(OC)c1OC</smiles>

Podophyllotoxin

(a)<smiles>COc1ccc(/C=C\c2cc(OC)c(OC)c(OC)c2)cc1O</smiles>

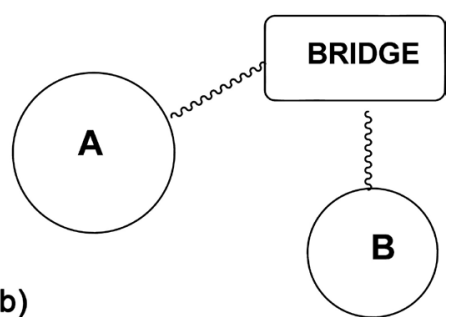

Figure 1. (a) Tubulin inhibitors that bind to colchicine binding site; (b) Common structure characteristic of CA-4.

CA-4 as a lead molecule for synthesis of new derivatives and more studied as tubulin inhibitors [5]. It is formed of three parts (2 carbons bridge, ring A and ring B) [6] (Figure 1(b)). Various changes to CA-4 structure have been performed in literature. The changes to the central bridge affect the cytotoxic activity the most [7]-[15]. Ring A has received little or no attention while ring B has received larger attention. Impressed by these finding, the double bond of CA- 4 is substituted by $\alpha$, $\beta$-unsaturated ketone, pyrazole, quinoline-3-carbonitriles, fused pyrimidine, fused quinazoline moieties, imine derivatives and 2-amino- $4 \mathrm{H}$-chromenes. Besides, ring $\mathrm{A}$ and $\mathrm{B}$ are replaced by 1, 5-diphenylpyrazole, naphthalene and pyrazole moieties. Those were evaluated in vitro for their anticancer tendency toward four cancer cell types. Additionally, molecular docking studies are performed and compared to biological results.

\section{Materials and Methods}

\subsection{Chemistry}

The new compounds are prepared by different pathways described in Scheme 1 and Scheme 2. The starting compound 3 was obtained via Vilsmeir Haack's formylation of the pyrazole derivatives using $\mathrm{POCl}_{3} / \mathrm{DMF}$ [16]. The $\alpha, \beta$ unsaturated carbonyl derivatives $\mathbf{4 a}, \mathbf{4 b}$ were synthesized via Claisen-Schmidt condensation [17] of cyclic ketones $4 \mathrm{a}, \mathrm{b}$ with substituted pyrazole-4-carbaldehyde $\mathbf{3}$ in an ethanolic solution of sodium hydroxide [18] [19] [20] [21] [22]. Cyclocondensation of enone $4 a$ with hydrazine hydrate or phenyl hydrazine using ethanol or glacial ethanoic acid afforded pyrazoles $5 \mathbf{a}-\mathbf{c}$ [23].

2-Substituted quinoline-3-carbonitrile products were made by the reaction of 
<smiles>[R]C=C1CCCc2c1nn([R])c2[R]</smiles>

5a-c
R: $5 \mathrm{a}=\mathrm{H}$

$5 b=\mathrm{C}_{6} \mathrm{H}_{5}$

$5 \mathrm{c}=\mathrm{COCH}_{3}$<smiles>[R]C=C1CCCc2c(nc([R10])c(O)c2[R])/C1=C\C</smiles><smiles>Cc1nn(-c2ccccc2)c(-c2ccccc2)c1C=O</smiles><smiles>C=Cc1c(C)n[nH]c1SC</smiles>

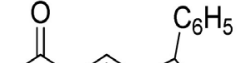

R: $6 a=\mathrm{CH}_{3} ; 6 b=\mathrm{C}_{2} \mathrm{H}_{5} ; 6 c=\mathrm{C}_{3} \mathrm{H}_{7}$ 3

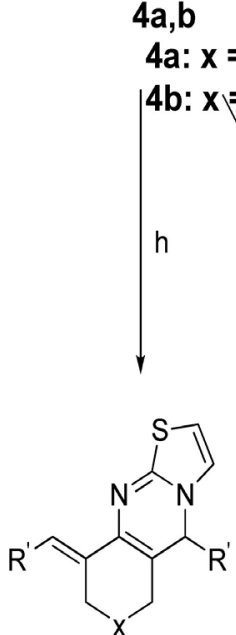

$11 a, b$<smiles>[R]c1c(C)nn(CCCC)c1[CH2-]</smiles><smiles>[R]C=C1CCc2c(nc(=S)[nH]c2[R])C1</smiles>

8<smiles>[R]C=C1CCCc2c1[nH]c(=N)c(C#N)c2[R]</smiles>
7

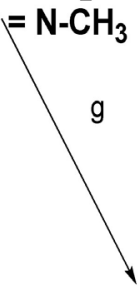

$10 a, b$<smiles>[3H]CCCC</smiles><smiles></smiles><smiles>CC#CC1CCCCC1</smiles>

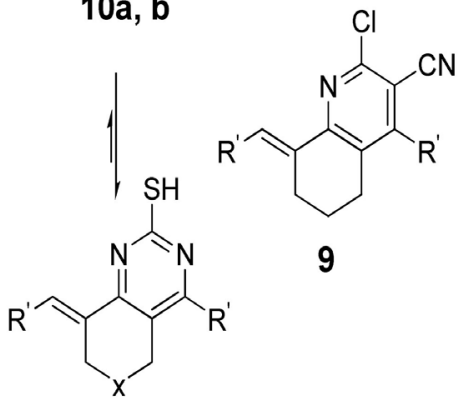

$10 a, b$

Scheme 1. Reagents and conditions: (a) cyclohexanone or N-methyl piperidone, alchoholic $\mathrm{NaOH}$; (b) $\mathrm{NH}_{2} \mathrm{NHR}$, absolute ethanol or $\mathrm{NH}_{2} \mathrm{NH}_{2}, \mathrm{AcOH}$; (c) malononitrile, sodium methoxide, sodium ethoxide or sodium propoxide, methanol, ethanol or n-propanol; (d) malononitrile, ammonium acetate, absolute ethanol; (e) ethylcyanoacetate, ammonium acetate, absolute ethanol; (f) $\mathrm{POCl}_{3} \backslash \mathrm{DEA}$; (g) thiourea, Na metal, butanol; (h) 2-aminothiazole, AcOH.

malononitrile with compounds $4 \mathrm{a}$ in sodium alkoxide to give the corresponding 2-alkoxyquinoline-3-carbonitriles derivatives 6a-c. Furthermore, a reaction of chalcone $4 \mathrm{a}$ with malononitrile and ammonium acetate in ethanol gave 2-aminoquinoline-3-carbonitrile derivative 7. Also, 2-oxoquinoline-3-carbonitrile 
8 was successfully synthesized by cyclocondensation reaction of compound $4 \mathrm{a}$ with ethylcyanoacetate and ammonium acetate in absolute ethanol. In another hand, chloro product $\mathbf{9}$ was collected by the reaction of compound $\mathbf{8}$ with $\mathrm{POCl}_{3}$ in catalytic amount of $N, N$-diethylaniline (DEA). Quinazoline-2-thione 10a, pyrido[4,3- $d$ ] pyrimidine-2-thione analogue $10 \mathrm{~b}$ were obtained by reaction of chalcone $4 \mathrm{a}, \mathrm{b}$ with thiourea in refluxing $\mathrm{NaOBu}$ in butyl alcohol [21]. Moreover, new derivatives of thiazolo[2,3-b] quinazoline $11 \mathrm{a}$ and thiazolo[3,2-a]pyrimidine $11 \mathrm{~b}$ were prepared by reacting 2 -aminothiazole with the enones $4 \mathrm{a}, \mathrm{b}$ in glacial ehanoic acid [18].

Other targeted imino derivatives $12 \mathrm{a}, \mathrm{b}$ and 13 were prepared via condensation of the pyrazole carbaldehyde 3 with the appropriate aromatic amine in glacial ethanoic acid [24] [25] (Scheme 2). Additionally, substituted malononitrile<smiles>Cc1nn(-c2ccccc2)c(-c2ccccc2)c1C=O</smiles>

3
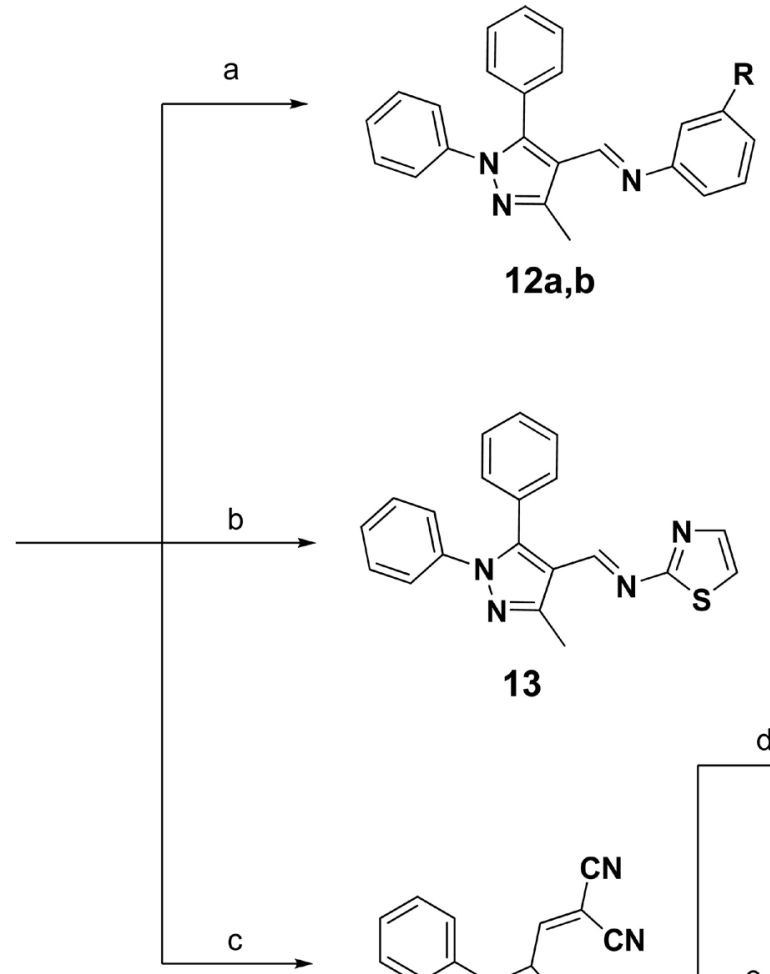

$12 a, b$<smiles>Cc1nn(-c2ccccc2)c(-c2ccccc2)c1/C=N/c1nccs1</smiles>

12a: $R=H$ 12b: $\mathrm{R}=\mathrm{CH}_{3}$
13

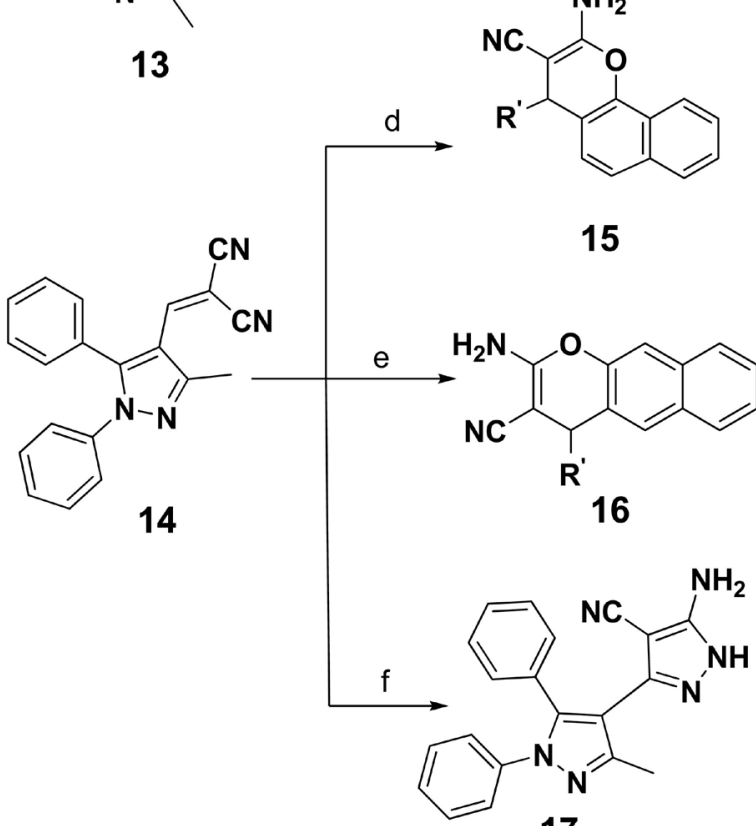

Scheme 2. Reagents and conditions: (a) aniline or $\mathrm{m}$-toluidine, $\mathrm{AcOH}$; (b) 2-aminothiazole, AcOH; (c) malononitrile, absolute ethanol; (d) $\alpha$-naphthol, methansulfonic acid; (e) $\beta$-naphthol, methansulfonic acid; (f) $\mathrm{NH}_{2} \mathrm{NH}_{2}$, absolute ethanol. 
nol. 2-Amino-4H-chromenes 15 and 16 were prepared from condensation of 14 was prepared from condensation of compound 3 with malononitrile in ethamalononitrile derivative 14 with naphthols using methanesulfonic acid [26]. Also, it was found that 5-amino-4-cyanopyrazole analogue 17 resulted when two moles of malononitrile derivative 14 condensed with one mole of hydrazine hydrate in absolute ethanol. All the analytical and spectroscopic data of the prepared compounds were fully accordance with their represented structures.

\subsection{Biology}

Four neoplastic cell types namely; (MCF-7), (HCT-116), (Hela) and (PC3) are obtained through VACSERA, Cairo, Egypt. Combretastatin A-4 was used as reference for judgment on anticancer activity of newly synthesized molecules.

The reagents RPMI-1640 medium, MTT, DMSO and CA-4 (sigma co., St. Louis, USA), Fetal Bovine blood serum (GIBCO, UK) [27].

The MTT assay was applied to assess cytotoxic activity using the cell lines mentioned above. This type of colorimetrical chemical assay relies on the modification of the yellow tetrazolium bromide (MTT) to a color of formazan derivative by mitochondrial succinate dehydrogenase in viable cells. Cell lines were cultured in RPMI-1640 medium with ten percent fetal bovine blood serum. Then, antibiotics added were one-hundred units/ml penicillin and one-hundred $\mu \mathrm{g} / \mathrm{ml}$ streptomycin at $37^{\circ} \mathrm{C}$ in a five percent $\mathrm{CO}_{2}$ incubator. Then, drugs were prepared in different concentrations and added to the cells, incubated for $24 \mathrm{hrs}$. After the period was completed, MTT solution $(20 \mu \mathrm{l})$ with concentration 5 $\mathrm{mg} / \mathrm{ml}$ was added to the mixture and incubated for $4 \mathrm{hrs}$. Then, DMSO (100 $\mu \mathrm{l})$ is sided to every single plate to remove purple color of formazan. The colorimetrical chemical assay is measured and recorded at an absorbance of $570 \mathrm{~nm}$ employing a plate reader (EXL 800, USA) [28] [29].

\subsection{Molecular Modeling}

The docking studies and modeling calculations were done using MOE version 2008.10 release of Chemical Computing Groups using Windows XP software. The 3D structures of the synthesized molecules were built using Chem Biooffice suite then saved as $\mathrm{Mol}_{2}$ format with the help of MOE software, then subjected to docking simulation. The three dimensional X-ray structure of protein (PDB code: 1SA1) was obtained from the Protein Data Bank.

\section{Results}

\subsection{Antitumor Activity}

All the synthesized compounds were evaluated for their cytotoxic activity toward a panel of 4 human neoplastic cell lines using the MTT assay. The results, in Table 1 showed that every compound have antitumor activities with noticeable differences due to structural variations.

As shown in Table 1 , compound 5 b with 2-phenyl substituted indazole 
Table 1. Cytotoxic activity (IC50, $\mu \mathrm{g} / \mathrm{ml})$ of (4-17).

\begin{tabular}{|c|c|c|c|c|c|c|}
\hline \multirow{2}{*}{ Compounds } & \multicolumn{6}{|c|}{ In vitro Cytotoxicity IC50 ( $\mu \mathrm{g} / \mathrm{ml})$} \\
\hline & $\mathrm{X}$ & $\mathbf{R}$ & HCT-116 & Hela & PC3 & MCF-7 \\
\hline $\mathrm{CA}-4$ & & & $\underline{10.5 \pm 0.73}$ & $\underline{9.4 \pm 0.61}$ & $\underline{20.2 \pm 1.12}$ & $\underline{5.3 \pm 0.42}$ \\
\hline $4 a$ & $\mathrm{CH}_{2}$ & & $58.7 \pm 3.65$ & $61.9 \pm 3.42$ & $53.0 \pm 2.98$ & $55.4 \pm 3.11$ \\
\hline $4 b$ & $\mathrm{~N}-\mathrm{CH}_{3}$ & & $27.6 \pm 1.98$ & $20.1 \pm 1.60$ & $26.2 \pm 1.82$ & $\underline{17.1 \pm 1.64}$ \\
\hline $5 a$ & & & $40.8 \pm 2.73$ & $33.5 \pm 2.06$ & $41.6 \pm 2.21$ & $37.5 \pm 2.30$ \\
\hline $5 b$ & & $\mathrm{Ph}$ & $\underline{8.6 \pm 0.51}$ & $\underline{8.2 \pm 0.73}$ & $\underline{12.7 \pm 0.88}$ & $\underline{6.9 \pm 0.51}$ \\
\hline $5 c$ & & $\mathrm{COCH}_{3}$ & $83.8 \pm 4.73$ & $>100$ & $>100$ & $84.9 \pm 3.99$ \\
\hline $6 a$ & & $\mathrm{CH}_{3}$ & $22.6 \pm 1.87$ & $\underline{14.9 \pm 1.23}$ & $\underline{17.7 \pm 1.41}$ & $\underline{14.0 \pm 1.41}$ \\
\hline $6 \mathrm{~b}$ & & $\mathrm{C}_{2} \mathrm{H}_{5}$ & $29.3 \pm 2.11$ & $38.9 \pm 2.25$ & $28.5 \pm 1.69$ & $\underline{20.4 \pm 1.85}$ \\
\hline $6 c$ & & $\mathrm{C}_{3} \mathrm{H}_{7}$ & $\underline{19.8 \pm 1.50}$ & $\underline{16.0 \pm 1.32}$ & $\underline{18.9 \pm 1.39}$ & $\underline{13.8 \pm 1.42}$ \\
\hline 7 & & & $63.4 \pm 3.98$ & $72.6 \pm 3.83$ & $74.5 \pm 3.85$ & $62.3 \pm 3.35$ \\
\hline 8 & & & $52.6 \pm 3.32$ & $80.4 \pm 4.05$ & $65.8 \pm 3.37$ & $51.1 \pm 2.89$ \\
\hline 9 & & & $70.6 \pm 4.52$ & $94.1 \pm 4.53$ & $97.3 \pm 4.60$ & $80.1 \pm 3.74$ \\
\hline $10 \mathrm{a}$ & $\mathrm{CH}_{2}$ & & $35.3 \pm 2.24$ & $50.5 \pm 2.89$ & $46.7 \pm 2.38$ & $31.8 \pm 2.15$ \\
\hline $10 \mathrm{~b}$ & $\mathrm{~N}-\mathrm{CH}_{3}$ & & $92.9 \pm 4.95$ & $>100$ & $93.1 \pm 4.12$ & $89.5 \pm 4.32$ \\
\hline $11 a$ & $\mathrm{CH}_{2}$ & & $96.4 \pm 5.24$ & $86.0 \pm 4.19$ & $82.9 \pm 3.93$ & $>100$ \\
\hline $11 b$ & $\mathrm{~N}-\mathrm{CH}_{3}$ & & $65.4 \pm 4.21$ & $69.4 \pm 3.60$ & $50.9 \pm 2.72$ & $77.8 \pm 3.58$ \\
\hline $12 a$ & & $\mathrm{H}$ & $34.1 \pm 2.36$ & $46.1 \pm 2.61$ & $36.0 \pm 1.94$ & $27.1 \pm 1.97$ \\
\hline $12 b$ & & $\mathrm{CH}_{3}$ & $45.2 \pm 2.92$ & $25.9 \pm 1.87$ & $\underline{20.0 \pm 1.47}$ & $39.9 \pm 2.52$ \\
\hline 13 & & & $\underline{14.4 \pm 1.05}$ & $\underline{11.4 \pm 0.98}$ & $\underline{15.6 \pm 1.20}$ & $\underline{9.1 \pm 1.10}$ \\
\hline 14 & & & $47.1 \pm 3.14$ & $57.1 \pm 3.18$ & $71.3 \pm 3.65$ & $45.6 \pm 2.64$ \\
\hline 15 & & & $\underline{10.8 \pm 0.92}$ & $9.5 \pm 0.84$ & $\underline{13.7 \pm 0.97}$ & $\underline{8.8 \pm 0.93}$ \\
\hline 16 & & & $\underline{9.0 \pm 0.68}$ & $\underline{7.8 \pm 0.42}$ & $\underline{12.2 \pm 0.81}$ & $\underline{7.9 \pm 0.68}$ \\
\hline 17 & & & $\underline{17.4 \pm 1.32}$ & $\underline{13.1 \pm 1.10}$ & $\underline{16.3 \pm 1.36}$ & $\underline{10.7 \pm 1.23}$ \\
\hline
\end{tabular}

IC50 = IC50 ( $\mu \mathrm{g} / \mathrm{ml}): 1-10$ (very strong). $11-20$ (strong). $21-50$ (moderate). $51-100$ (weak) and above 100 (non-cytotoxic). CA-4 = combretastatin A-4.

shows wide spectrum cytotoxic activity with IC50 starting from 6.9 to $12.7 \mu \mathrm{M}$. Replacement of phenyl ring with acetyl group as in compound $5 c$ or unsubstituted indazole in compound $\mathbf{5 a}$ and uncyclized chalcone as in compound $\mathbf{4 a}$ exhibited a decrease within the activity against the four cell lines. Additionally, the cytotoxic activities of recent synthesized quinoline-3-carbonitrile 6-9, compounds $6 \mathrm{a}$ with 2 -methoxy and $6 \mathrm{c}$ with 2-propoxy group has broad spectrum activity virtually identical IC50, $(22.6 \pm 1.87$ for HCT-116, $14.9 \pm 1.23$ for Hela, $17.7 \pm 1.41$ for PC3, $14.0 \pm 1.41$ for MCF-7), $(19.8 \pm 1.50$ for HCT-116, $16.0 \pm$ 1.32 for Hela, $18.9 \pm 1.39$ for PC3, $13.8 \pm 1.42$ for MCF-7) respectively. In comparison to compound $6 \mathrm{c}$, replacing propoxy group with ethoxy group in compound $\mathbf{6 b}$ resulting in 1.5 times decrease in cytotoxic activity. Also replacing propoxy group with amino group in compound 7 resulting in reduce in activity 
by almost 4 times. Compounds 8 and 9 shows low activity within the four cell lines. By replacing $\mathrm{CH}_{2}$ of cyclohexanone chalcone $4 \mathrm{a}$ by $\mathrm{N}-\mathrm{CH}_{3}$ chalcone $4 \mathrm{~b}$, the cytotoxic activity is almost doubled against the four human cell lines. While the cytotoxic activity of $10 \mathrm{a}$ and $11 \mathrm{~b}$ is ranged from moderate to weak activity but compounds $10 \mathrm{~b}$ and $11 \mathrm{a}$ are inactive with IC50 $>100 \mu \mathrm{g} / \mathrm{ml}$.

Also, the series of 4-substituted 1,5-diphenyl pyrazole shows a range of intermediate to high cytotoxicity activity. Compounds with benzo chromene-3carbonitrile substitution as in $\mathbf{1 5}$ and $\mathbf{1 6}$ results in very strong cytotoxic activity with IC50, (10.8 \pm 0.92 for HCT-116, $9.5 \pm 0.84$ for Hela, $13.7 \pm 0.97$ for PC3, 8.8 \pm 0.93 for MCF-7) and $(9.0 \pm 0.68$ for HCT-116, $7.8 \pm 0.42$ for Hela, $7.9 \pm 0.68$ for PC3, $12.2 \pm 0.81$ for MCF-7) respectively. Replacement of aniline or substituted aniline in compounds $12 \mathrm{a}$, b by either 2 -amino thiazole in compound 13 or substituted pyrazole in compound 17 enhance cytotoxic activity with IC50, $(11.4 \pm 0.98$ for HCT-116, $14.4 \pm 1.05$ for Hela, $15.6 \pm 1.20$ for PC3, $9.1 \pm 1.10$ for MCF-7) and (17.4 \pm 1.32 for HCT-116, $13.1 \pm 1.10$ for Hela, $16.3 \pm 1.36$ for PC3, $10.7 \pm 1.23$ for MCF-7) respectively.

\subsection{Molecular Modeling}

Molecular docking was performed for compounds that inhibited tubulin polymerization so as to explore attainable binding modes. The tubulin protein structure in complex with podophyllotoxin (PDB 1SA1) was used for the study [30] [31] [32]. In molecular docking, MOE programme (molecular operating environment) was used in our study. CA-4 is employed as lead compound due to its excellent affinity to colchicine binding site (Figure 2). Comparing to the lead molecule CA-4 and biological activity, we have a tendency to found that compounds 5b, 15, 16 and 17 have the lowest energy and give the most stable complexes with the receptor and are the most biological active against cell lines so we concluded that these new compounds have very good affinity binding with the protein. During this study, we observed that basic amino acid Lys (B254) is essential as it is bound with 15 via arene cation interaction and with 16 via hydrogen bond (angle NH... $\mathrm{N}=101.9$, distance $=2.9 \mathrm{~A}^{0}$ ) (Figure 4, Figure 5). Also, it was found that Tyr (A224) is important for arene-arene interaction with 5b, 15 and 17 (Figure 3, Figure 4, Figure 6). Also, Glu (A183) is bound to the amino group in 15 (Figure 4) via hydrogen bond (angle $\mathrm{NH} . . \mathrm{O}=111.9$, distance $=2.8 \mathrm{~A}^{0}$ ). A Hydrogen bond is formed between a nitrogen atom in nitrile group in 17 (Figure 6) and hydroxyl side chain of ser (A140) (angle N...HO =1 02.9 , distance $=2.7 \mathrm{~A}^{0}$ ).

\section{Experimental}

Melting points $\left({ }^{\circ} \mathrm{C}\right)$ were recorded using a Fisher-Johns melting point apparatus and are uncorrected. Microanalyses $(\mathrm{C}, \mathrm{H}$, and $\mathrm{N}$ ) were performed in Cairo University Microanalytical unit, and all the results within \pm 0.4 . IR spectra $(\mathrm{KBr})$ were recorded on Thermo Fisher Scientific Nicolet IS10. Spectrometer ( $v$ in 


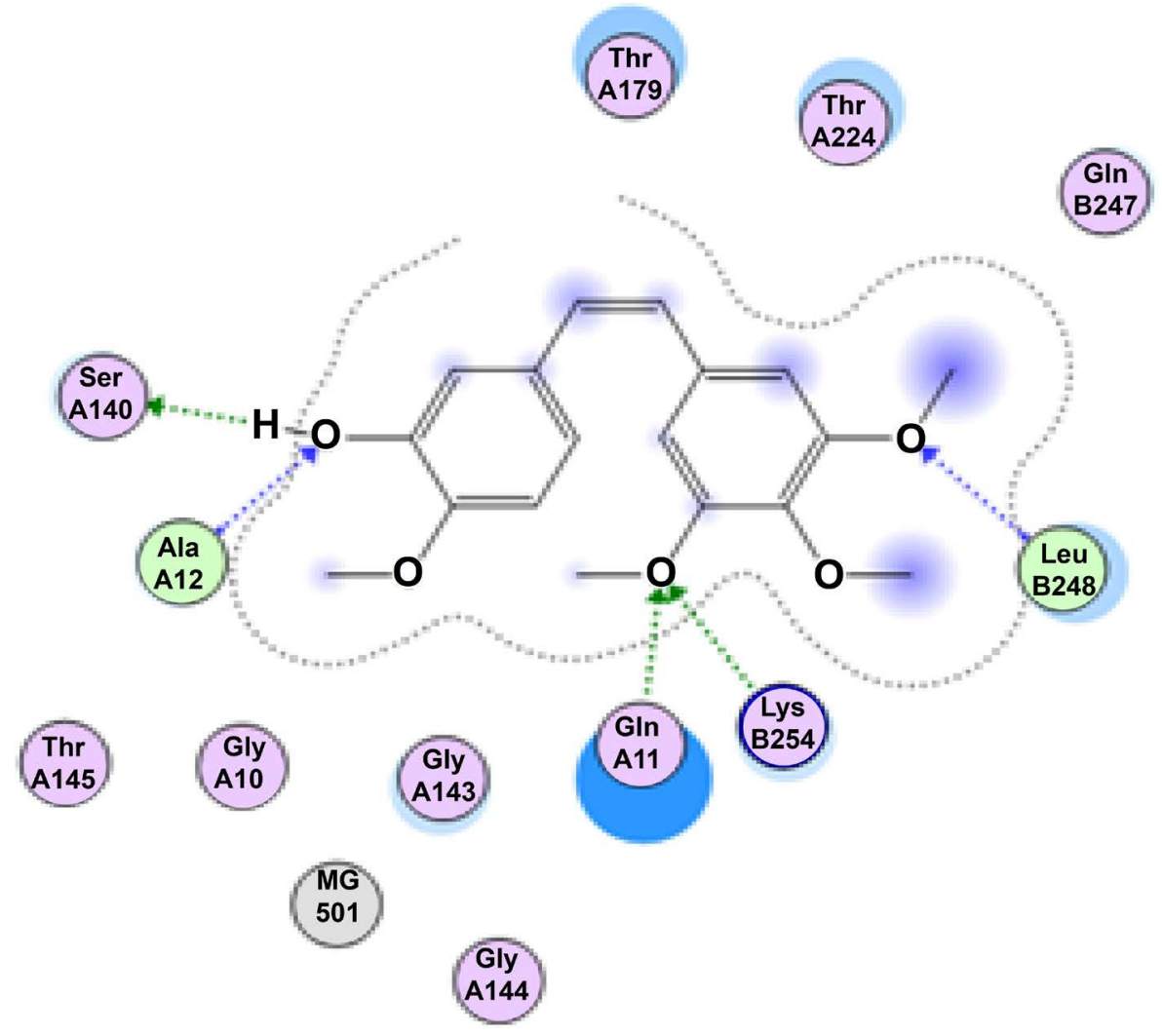

Figure 2. Binding of CA-4 with 1SA1 amino acids. (a) Gln: Glutamine; (b) Lys: Lysine; (c) Ala: Alanine; (d) Ser: Serine.

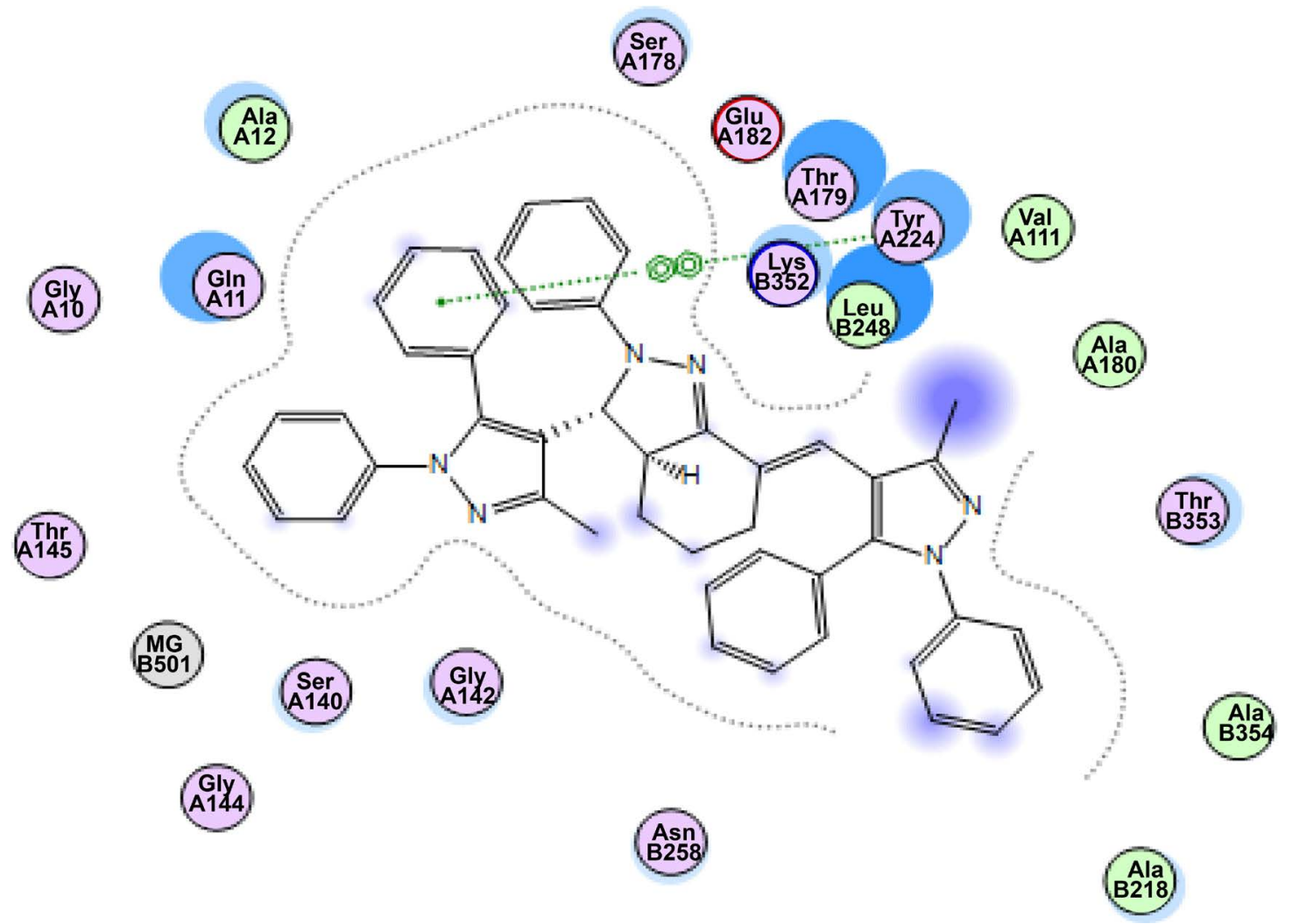

Figure 3. Binding of 5b with $1 \mathrm{SA} 1$ amino acids. (a) Tyr: Tyrosine. 


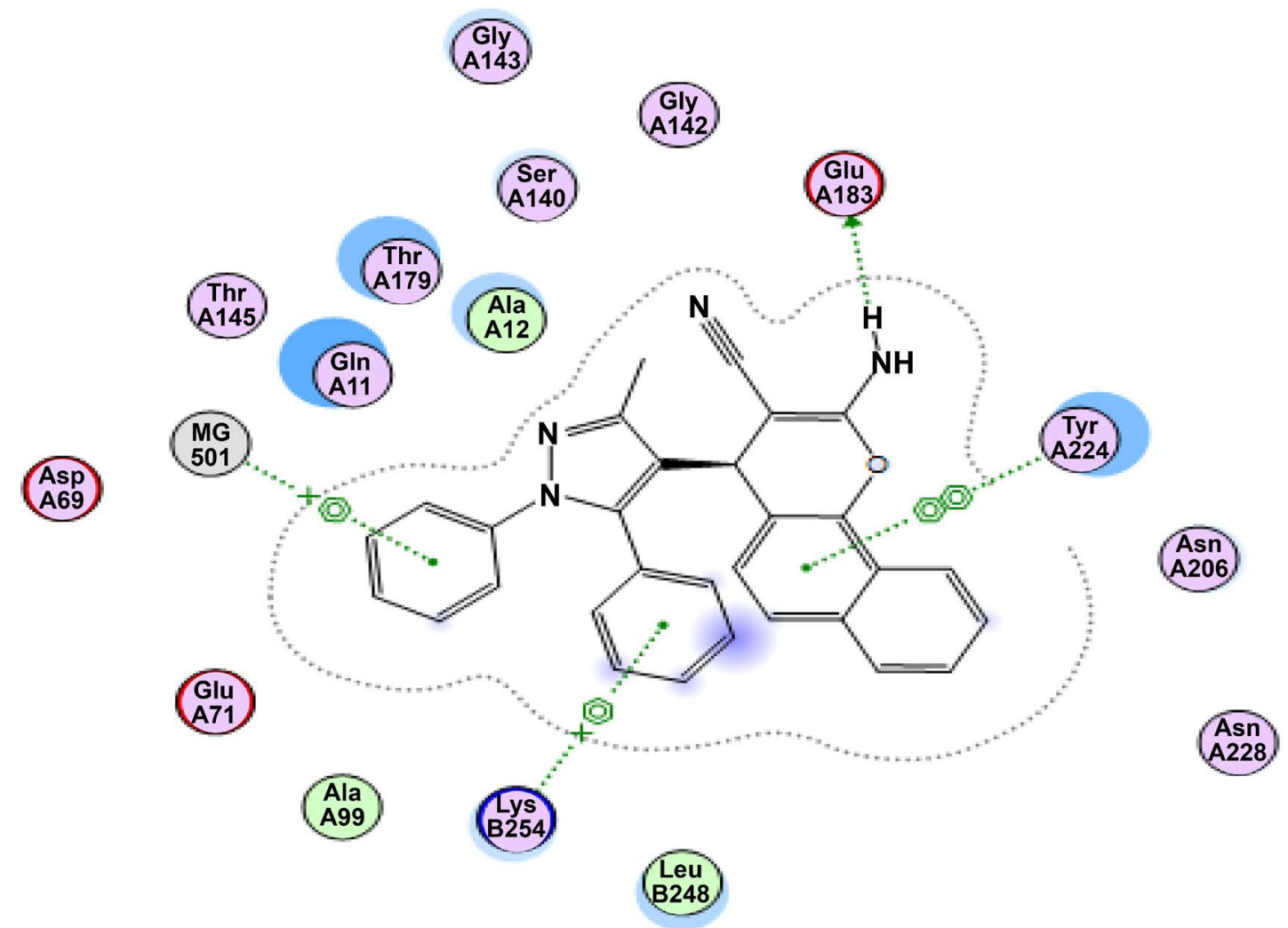

Figure 4. Binding of 15 with 1SA1 amino acids. (a) Lys: Lysine; (b) Tyr: Tyrosine; (c) Glu: Glutamic acid; (d) $\mathrm{Mg}^{+2}$ cation.

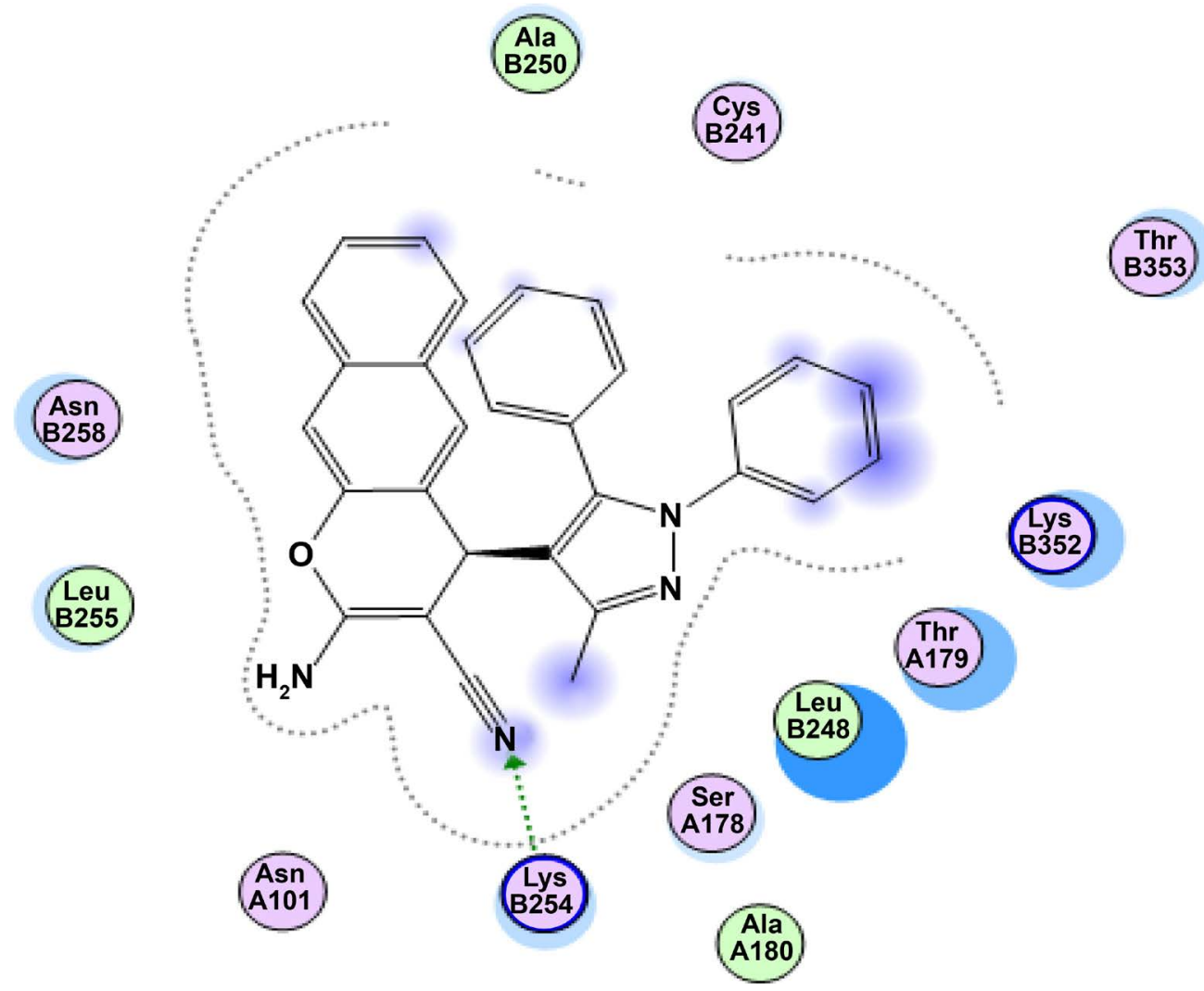

Figure 5. Binding of 16 with $1 \mathrm{SA} 1$ amino acids. (a) Lys: Lysine. 

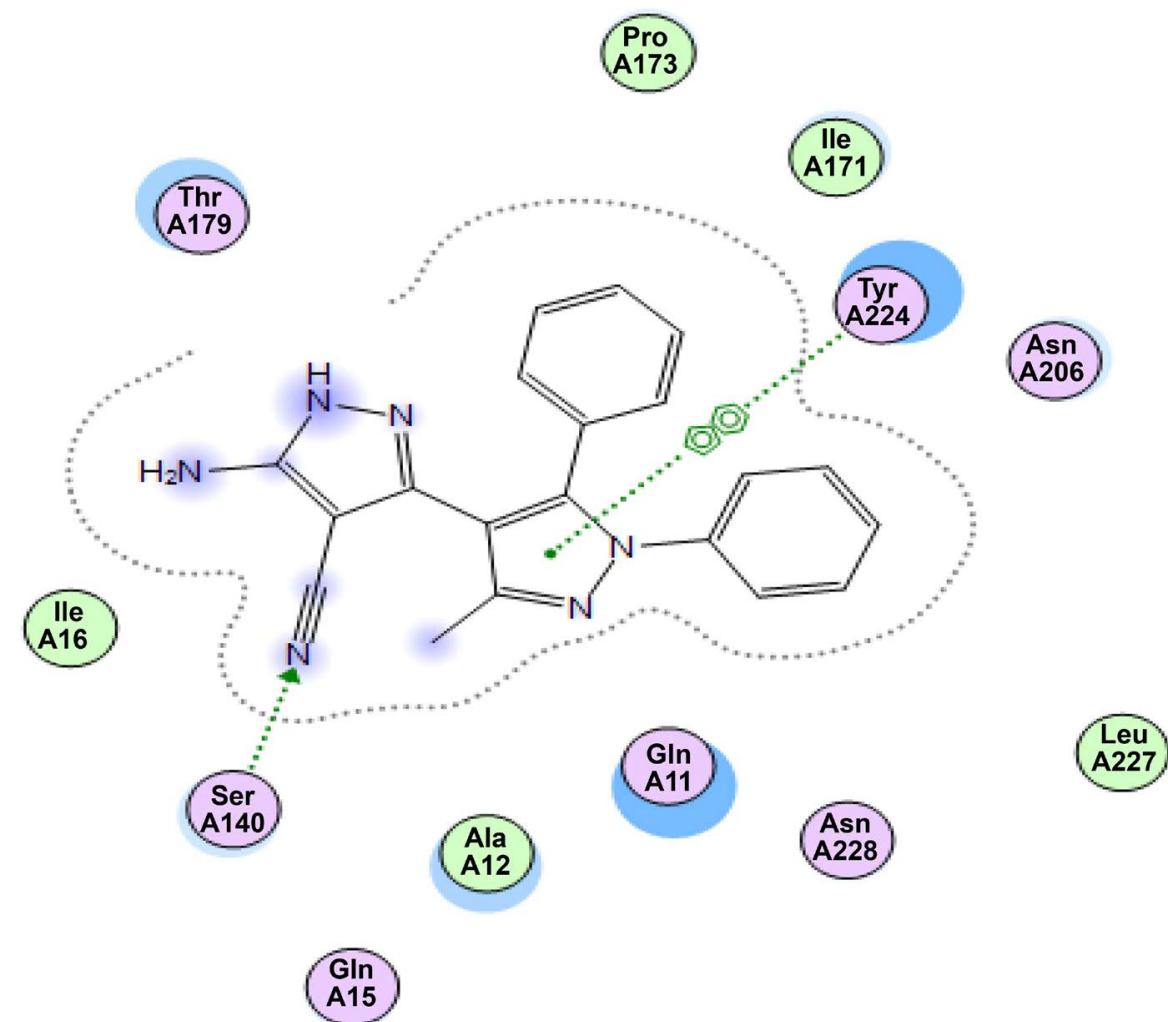

Figure 6. Binding of 17 with 1 SA1 amino acids. (a) Tyr: Tyrosine; (b) Ser: Serine.

$\mathrm{cm}^{-1}$ ) at Faculty of Pharmacy, Mansoura University. Mass MS (EI) $\mathrm{m} / z$ analyses were performed on Thermo Scientific DCQII, Faculty of Science, Mansoura University. ${ }^{1} \mathrm{H}$ and ${ }^{13} \mathrm{C}-\mathrm{NMR}$ spectra were obtained in DMSO- $d_{6}$ or $\mathrm{CDCl}_{3}$ on ASCEND spectrometer (400 MHz) Bruker at Georgia State University USA, Faculty of Pharmacy, Zagazig University and Faculty of Science, Kafr ElSheikh University. Reaction times were decided using TLC on Silica gel plates 60 F254 (E. Merk), and the spots were visualized by U.V (366, $245 \mathrm{~nm}$ ). Compounds 2, 3 were prepared as previously discussed in literature [16] [33].

\subsection{General Method for Preparation of Chalcones 4a, b}

Ethanolic solution $(20 \mathrm{ml})$ of $\mathrm{NaOH}(1 \mathrm{~g}, 0.025 \mathrm{~mol})$ was mixed with a solution of 3-methyl-1,5-diphenyl-1H-pyrazole-4-carbaldehyde (3) $(1 \mathrm{~g}, 0.02 \mathrm{~mol})$ and the appropriate cyclic ketones $(0.01 \mathrm{~mol})$ in ethyl alcohol $(30 \mathrm{ml})$. The previous mixture was stirred at $25^{\circ} \mathrm{C}$ for $2 \mathrm{~h}$. The product obtained was then filtered, washed with water, dried and finally recrystallized from ethyl alcohol.

(2E,6E)-2,6-bis[(3-Methyl-1,5-diphenyl-1 $H$-pyrazol-4-yl)methylene]cycl ohexanone (4a) as yellow solid; yield $45 \%(1 \mathrm{~g}) ; \mathrm{mp} 230^{\circ} \mathrm{C}-233^{\circ} \mathrm{C} ;{ }^{1} \mathrm{H}$ NMR $\left(\right.$ DMSO- $\left.d_{6}\right): \delta 7.2-7.3(\mathrm{~m}, 20 \mathrm{H}, \mathrm{Ar}-\mathrm{H}), 7.1(\mathrm{~d}, J=8.1 \mathrm{~Hz}, 2 \mathrm{H}$, methylene-H), 2.5 $\left(\mathrm{s}, 6 \mathrm{H}, 2 \mathrm{CH}_{3}\right), 2.1(\mathrm{~s}, 4 \mathrm{H}$, cyclohexanone- $\mathrm{H}), 1.6(\mathrm{q}, J=7.1 \mathrm{~Hz}, 2 \mathrm{H}$, cyclohexanone-H); ${ }^{13} \mathrm{C}$ NMR: $\delta 13$ (2c), 25.7 (1c), 26.1 (2c) 115.7 (2c), 124.5 (4c), 126.2 (2c), 127.5 (4c), 128 (2c), 129.2 (4c), 129.3 (4c), 133 (2c), 139.8 (2c), $142.2(2 \mathrm{c})$, 143.8 (2c), 147.9 (2c), 150 (2c), 191 (1c); IR $\left(\mathrm{KBr}, \mathrm{cm}^{-1}\right): 1670(\mathrm{C}=\mathrm{O}), 1627$ 
$(\mathrm{C}=\mathrm{N})$, 1547, 1489 (C=C); MS (EI) $m / z$ : 586 (30\%, M+); anal (calcd.) for $\mathrm{C}_{40} \mathrm{H}_{34} \mathrm{~N}_{4}, \mathrm{C}: 81.88, \mathrm{H}: 5.84, \mathrm{~N}: 9.55$. Found, C: $81.87, \mathrm{H}: 5.85, \mathrm{~N}: 9.04$.

(3E,5E)-1-Methyl-3,5-bis[(3-methyl-1,5-diphenyl-1 $H$-pyrazol-4-yl)methy lene]piperidin-4-one (4b) as brown solid; yield $75 \%(0.8 \mathrm{~g}) ; \mathrm{mp} 300^{\circ} \mathrm{C}-302^{\circ} \mathrm{C}$; ${ }^{1} \mathrm{H}$ NMR (DMSO- $\left.d_{6}\right): 7.1$ - 7.7 (m, 22H, Ar-H, 2H-methylene), 4.1 (s, 4H, $\left.\mathrm{CH}_{2} \mathrm{NCH}_{2}\right), 2.5\left(\mathrm{~s}, 6 \mathrm{H}, 2 \mathrm{CH}_{3}\right), 2.2\left(\mathrm{~s}, 3 \mathrm{H}, \mathrm{N}-\mathrm{CH}_{3}\right)$; IR $\left(\mathrm{KBr}, \mathrm{cm}^{-1}\right): 1670(\mathrm{C}=\mathrm{O})$; MS (EI) $m / z$ : 601 (98.9\%, M+); anal (calcd.) for $\mathrm{C}_{40} \mathrm{H}_{35} \mathrm{~N}_{5}, \mathrm{C}: 79.84, \mathrm{H}: 5.86, \mathrm{~N}$ : 11.64. Found, C: $79.88, \mathrm{H}: 5.85, \mathrm{~N}: 11.55$.

\subsection{General Procedure for Synthesis of 5a, c}

Hydrazine hydrate $(98 \%)(0.3 \mathrm{ml}, 0.05 \mathrm{~mol})$ introduced to a solution of $4 \mathrm{a}$ in ethyl alcohol (99\%) $(20 \mathrm{ml}) 5 \mathrm{a}$ or ethanoic acid $(10 \mathrm{ml}) 5 \mathrm{c}$ and the mixture was refluxed for $5 \mathrm{~h}$. The solvent was decreased using evaporator. After cooling the separated product was filtered, dried and finally recrystallized from ethyl alcohol.

\subsection{General Procedure for Synthesis of 5b}

A mixture of chalcone $4 \mathrm{a}(0.7 \mathrm{~g}, 0.005 \mathrm{~mol})$, phenyl hydrazine $(0.12 \mathrm{~g}, 0.005$ $\mathrm{mol})$ in glacial ethanoic acid $(15 \mathrm{ml})$ was heated for $8 \mathrm{~h}$. Then the mixture was diluted with ice-cold water. The precipitate was collected, washed with water, dried and purified by $\mathrm{SiO}_{2}$ (preparative TLC in petroleum ether: ethyl acetate $3: 1)$

3-(3-Methyl-1,5-diphenyl-1 $H$-pyrazol-4-yl)-7-( $E$ ) [(3-methyl-1,5-dipheny 1-1 $H$-pyrazol-4-yl)methylene]-3,3a,4,5,6,7-hexahydro- $H$-indazole (5a): (1 $\mathrm{g}, 0.01 \mathrm{~mol})$ of compound $4 \mathrm{a}$ gave $5 \mathrm{a}$ as white powder; yield $40 \%(0.4 \mathrm{~g}) ; \mathrm{mp}$ $150^{\circ} \mathrm{C}-155^{\circ} \mathrm{C} ;{ }^{1} \mathrm{H}$ NMR (DMSO- $\left.d_{6}\right): \delta 8.1$ (s, $1 \mathrm{H}, \mathrm{NH}\left(\mathrm{D}_{2} \mathrm{O}\right.$ exchangeable), 7.1 $7.3(\mathrm{~m}, 21 \mathrm{H}, 20 \mathrm{Ar}-\mathrm{H}$, methylene- $\mathrm{H}), 2.5\left(\mathrm{~s}, 3 \mathrm{H}, \mathrm{CH}_{3}\right), 2.2(\mathrm{t}, J=7.7 \mathrm{~Hz}, 2 \mathrm{H}$, indazole $\mathrm{H}-4), 2.1$ (s, 3H, $\left.\mathrm{CH}_{3}\right), 1.9\left(\mathrm{~m}, 4 \mathrm{H}\right.$, indazole- $\left.\mathrm{H}_{5}, \mathrm{H}_{6}\right)$; IR $\left(\mathrm{KBr}, \mathrm{cm}^{-1}\right)$ : absence of $\mathrm{C}=\mathrm{O}$ at $1670,3410(\mathrm{NH})$; MS (EI) $\mathrm{m} / \mathrm{z}$. 600 (8.8\%, M+); anal (calcd.) for $\mathrm{C}_{40} \mathrm{H}_{34} \mathrm{~N}_{6}$, C: 79.97, H: 6.04, N: 13.99. Found, C: 79.85, H: 6.01, N: 13.78.

3-(3-methyl-1,5-diphenyl-1 $H$-pyrazol-4-yl)-7-( $E$ ) [(3-methyl-1,5-diphenyl -1 $H$-pyrazol-4-yl)methylene]-2-phenyl-3,3a,4,5,6,7-hexahydro- $2 H$-indazole (5b): as yellow solid; yield $83 \%(0.5 \mathrm{~g})$; mp $129^{\circ} \mathrm{C}-130^{\circ} \mathrm{C} .{ }^{1} \mathrm{H}$ NMR (DMSO- $\left.d_{6}\right)$ : $\delta 7.4$ - 7.7 (m, 26H, Ar-H, methylene-H), 2.7 (t, $J=7.3 \mathrm{~Hz}, 2 \mathrm{H}$, indazole-H4), 2.4 (s, 3H, $\mathrm{CH}_{3}$-pyrazole), 2.1 (s, 3H, $\mathrm{CH}_{3}$-pyrazole), $1.9(\mathrm{~m}, J=7.1 \mathrm{~Hz}, 4 \mathrm{H}$, indazole $-\mathrm{H} 5, \mathrm{H} 6)$; IR $\left(\mathrm{KBr}, \mathrm{cm}^{-1}\right): 1598(\mathrm{C}=\mathrm{C})$, absence of $\mathrm{C}=\mathrm{O}$ at 1670; MS (EI) $\mathrm{m} / z$ : 676 (31\%, M+); anal calcd for $\mathrm{C}_{46} \mathrm{H}_{38} \mathrm{~N}_{6}: \mathrm{C}: 81.63, \mathrm{H}: 5.96, \mathrm{~N}: 12.42$. Found: $\mathrm{C}$, 81.53, H: $5.87 \mathrm{~N}: 12.38$.

1-\{[3-(3-Methyl-1,5-diphenyl-1 $H$-pyrazol-4-yl)-7-( $E$ ) [(3-methyl-1,5-diph enyl- $1 H$-pyrazol-4-yl)methylene]-3,3a,4,5,6,7-hexahydro-2 $H$-indazol-2-yl $\}$ e thanone $(5 \mathrm{c}):(0.7 \mathrm{~g}, 0.005 \mathrm{~mol})$ of compound $4 \mathrm{a}$ gave $5 \mathrm{c}$ as buff solid; yield $57 \%$ $(0.4 \mathrm{~g}) ; \mathrm{mp} 138^{\circ} \mathrm{C}-140^{\circ} \mathrm{C} ;{ }^{1} \mathrm{H}$ NMR (DMSO- $\left.d_{6}\right): \delta 7.1-7.3(\mathrm{~m}, 21 \mathrm{H}, 20 \mathrm{Ar}-\mathrm{H}$, methylene-H), 2.7 (t, $J=7.7 \mathrm{~Hz}, 2 \mathrm{H}$, indazole $\mathrm{H}-4), 2.2\left(\mathrm{~s}, 3 \mathrm{H}, \mathrm{COCH}_{3}\right), 2.5$ (s, 
3H, $\mathrm{CH}_{3}$-pyrazole), 2.1 (s, 3H, $\mathrm{CH}_{3}$-pyrazole), 1.9 (m, $4 \mathrm{H}$, indazole- $\left.\mathrm{H}_{5}, \mathrm{H}_{6}\right)$; IR $\left(\mathrm{KBr}, \mathrm{cm}^{-1}\right): 1656(\mathrm{C}=\mathrm{O}), 1504(\mathrm{C}=\mathrm{C}) ; \mathrm{MS}(\mathrm{EI}) \mathrm{m} / \mathrm{z}: 642$ (59\%, M+); anal (calcd.) for $\mathrm{C}_{42} \mathrm{H}_{36} \mathrm{~N}_{6}, \mathrm{C}: 78.33, \mathrm{H}: 5.85, \mathrm{~N}: 13.99$. Found, C: 78.5, H: 5.01, N: 13.78 .

\subsection{Preparation of $6 a-c$}

A mixture of compound $4 \mathrm{a}(0.6 \mathrm{~g}, 1 \mathrm{mmol})$ and malononitrile $(0.07 \mathrm{~g}, 1 \mathrm{mmol})$ was added to freshly prepared solution of sodium alkoxide $(15 \mathrm{ml}),(0.3 \mathrm{~g}, 0.014$ mol) of sodium in $100 \mathrm{ml}$ of the appropriate alcohol. The mixture kept at room temperature for the ideal time. The triggered product became collected by filtration, washed with ethanol and recrystallized from ethanol/ DMF.

2-Methoxy-4-(3-methyl-1,5-diphenyl-1 $H$-pyrazol-4-yl)-8-(E) [(3-methyl1,5-diphenyl-1 $H$-pyrazol-4-yl)methylene]-5,6,7,8-tetrahydroquinoline-3-ca rbonitrile (6a) as white solid; yield $66 \%(0.4 \mathrm{~g})$; m.p $160^{\circ} \mathrm{C}-163^{\circ} \mathrm{C}$; ${ }^{1} \mathrm{H}$ NMR (DMSO- $\left.d_{6}\right): \delta 8.1(\mathrm{~s}, 1 \mathrm{H}$, methylene-H), $7.4-7.7(\mathrm{~m}, 20 \mathrm{H}, 20 \mathrm{Ar}-\mathrm{H}), 4.1(\mathrm{~s}, 3 \mathrm{H}$, $\left.\mathrm{OCH}_{3}\right), 3.1\left(\mathrm{t}, J=7.5 \mathrm{~Hz}, 2 \mathrm{H}\right.$, quinoline-H5), $2.5\left(\mathrm{~s}, 6 \mathrm{H}, 2 \mathrm{CH}_{3}\right), 2.1(\mathrm{~m}, 4 \mathrm{H}$, quinoline-H6, H7); ${ }^{13} \mathrm{C}$ NMR: $\delta 11.6(1 \mathrm{c}), 12.5$ (1c), 21.5 (1c), 26.7 (1c), 32.2 (1c), 54.1 (1c), 111.7 (1c), 112.2 (1c), 116.3 (1c), 119.7 (1c), 120.8 (1c), 123.9 (2c), 124.8 (2c), 126.5 (1c), 127 (1c), 128.2 (1c), 128.4 (2c), 128.51 (4c), 128.6 (4c), 129.3 (2c), 129.8 (2c), 129.9 (2c), 130.3 (1c), 131 (1c), 139.4 (1c), 139.6 (1c), 139.9 (1c), 140.5 (1c), 141 (1c), 147.2 (1c), 147.4 (1c), 159.5 (1c); IR $\left(\mathrm{KBr}, \mathrm{cm}^{-1}\right)$ : absence of CO peak at 1670, 2221 (CN), 1598 (CN ring); MS (EI) m/z. 664.9 (69\%, M+); anal. calcd for $\mathrm{C}_{44} \mathrm{H}_{36} \mathrm{~N}_{6}$ : C: 79.49, H: 5.46, N: 12.64. Found: C: 79.2, H: 5.41, N: 12.64 .

2-Ethoxy-4-(3-methyl-1,5-diphenyl-1 $H$-pyrazol-4-yl)-8-( $E$ ) [(3-methyl-1, 5-diphenyl-1 $H$-pyrazol-4-yl)methylene]-5,6,7,8-tetrahydroquinoline-3-carb onitrile (6b) as buff solid; yield $50 \%(0.3 \mathrm{~g}) ; \mathrm{mp} 130^{\circ} \mathrm{C}-135^{\circ} \mathrm{C} ;{ }^{1} \mathrm{H}$ NMR (DMSO- $\left.d_{6}\right): \delta 6.5-7.3\left(\mathrm{~m}, 21 \mathrm{H}, 20 \mathrm{Ar}-\mathrm{H}, \mathrm{H}\right.$-methylene), $3.8\left(\mathrm{~m}, 2 \mathrm{H}, \mathrm{OCH}_{2}\right), 3.1$ $(\mathrm{t}, 2 \mathrm{H}, \mathrm{J}=7.1 \mathrm{~Hz}$, quinoline $\mathrm{H}-5), 2.5\left(\mathrm{~s}, 6 \mathrm{H}, 2 \mathrm{CH}_{3}\right), 2.1(\mathrm{~m}, 4 \mathrm{H}$, quinoline- $\mathrm{H} 6$, H7), $1.6\left(\mathrm{t}, J=7.5 \mathrm{~Hz}, 3 \mathrm{H}, \mathrm{CH}_{3}\right)$; IR $\left(\mathrm{KBr}, \mathrm{cm}^{-1}\right)$ : absence of CO, $2220(\mathrm{CN})$; MS (EI) $\mathrm{m} / z$ : $678(12 \%, \mathrm{M}+)$; anal. calcd for $\mathrm{C}_{45} \mathrm{H}_{38} \mathrm{~N}_{6}$ : C: $79.62, \mathrm{H}: 5.64, \mathrm{~N}: 12.38$. Found: C: 79.21, H: 5.43, N: 12.04 .

4-(3-Methyl-1,5-diphenyl-1 $H$-pyrazol-4-yl)-8-( $E$ ) [(3-methyl-1,5-dipheny 1-1 $H$-pyrazol-4-yl)methylene]-2-propoxy-5,6,7,8-tetrahydroquinoline-3-car bonitrile (6c) as white solid; yield $71 \%(0.5 \mathrm{~g}) ; \mathrm{mp} 141^{\circ} \mathrm{C}-142.5^{\circ} \mathrm{C} ;{ }^{1} \mathrm{H}$ NMR (DMSO- $\left.d_{6}\right): \delta 8.1$ (s, $1 \mathrm{H}, \mathrm{H}$-methylene), $7.5-7.8(\mathrm{~m}, 20 \mathrm{H}, 20 \mathrm{Ar}-\mathrm{H}), 3.8(\mathrm{t}, J=7.8$ $\left.\mathrm{Hz}, 2 \mathrm{H}, \mathrm{OCH}_{2}\right), 3.1\left(\mathrm{t}, 2 \mathrm{H}, J=7.1 \mathrm{~Hz}\right.$, quinoline-H5), $2.5\left(\mathrm{~s}, 6 \mathrm{H}, 2 \mathrm{CH}_{3}\right), 1.9(\mathrm{~m}$, $4 \mathrm{H}$, quinolineH6, $\mathrm{H} 7), 1.8\left(\mathrm{~m}, 2 \mathrm{H}, \mathrm{C}-\mathrm{CH}_{2}\right), 1.6\left(\mathrm{~m}, 3 \mathrm{H}, \mathrm{CH}_{3}\right) ;{ }^{13} \mathrm{CNMR}: \delta 11.6$ (2c), 12.5 (2c), 21.5 (1c), 26.7 (1c), 32.3 (1c), 54.1 (1c), 111.7 (1c), 112.2 (1c), 116.3 (1c), 119.7 (1c), 120.8 (1c), 123.9 (2c), 124.8 (2c), 126.5 (1c), 127 (1c), 128.2 (1c), 128.4 (2c), 128.51 (2c), 128.59 (2c), 128.6 (2c), 128.7 (2c), 129.3 (2c), 129.8 (2c), 129.9 (2c), 130.3 (1c), 131 (1c), 139.4 (1c), 139.6 (1c), 139.9 (1c), 140.5 (1c), 141 (1c), 147.2 (1c), 147.4 (1c), 159.5 (1c); IR ( $\left.\mathrm{KBr}, \mathrm{cm}^{-1}\right)$ : absence of CO, 2221 (CN), 1598 (CN ring); MS (EI) m/z. 692 (20\%, M+); anal. calcd for $\mathrm{C}_{46} \mathrm{H}_{40} \mathrm{~N}_{6}:$ C: 79.74, H: 5.82, N: 12.13. Found: C: 79.03, H: 5.31, N: 12.11. 


\subsection{Preparation of}

2-Amino-4-(3-Methyl-1,5-Diphenyl-1H-Pyrazol-4-yl)-8-(E)

[(3-Methyl-1,5-Diphenyl-1H-Pyrazol-4-yl) Methylene]

-5,6,7,8-Tetrahydroquinoline-3-Carbonitrile (7)

Compound 4a (2.6 g, $0.005 \mathrm{~mol})$ was mixed with malononitrile $(0.3 \mathrm{~g}, 0.005$ $\mathrm{mol}$ ) and ammonium acetate $(2.7 \mathrm{~g}, 0.04 \mathrm{~mol})$ in ethyl alcohol (99\%) (30 $\mathrm{ml})$. The mixture was refluxed for $7 \mathrm{~h}$, and then concentrated under reduced pressure. After cooling, the precipitated product was filtered, dried and purified by $\mathrm{SiO}_{2}$ (preparative TLC petroleum ether: ethyl acetate 3:1) to yield compound 7 as yellow powder; yield $71 \%(2 \mathrm{~g}) ; \mathrm{mp} 300^{\circ} \mathrm{C}-302^{\circ} \mathrm{C}$; ${ }^{1} \mathrm{H}$ NMR (DMSO- $\left.d_{6}\right): \delta$ 7.1 - 7.3 (m, 21H, Ar-H, H-methylene), 6.7 (s, 2H, $\mathrm{NH}_{2}$ (D2O exchangeable), 3.1 $\left(\mathrm{t}, 2 \mathrm{H}, J=7.1 \mathrm{~Hz}\right.$, quinoline-H5), $2.5\left(\mathrm{~s}, 3 \mathrm{H}, \mathrm{CH}_{3}\right), 2.1\left(\mathrm{~s}, 3 \mathrm{H}, \mathrm{CH}_{3}\right), 1.9(\mathrm{~m}, 4 \mathrm{H}$, quinolineH6, H7); IR ( $\left.\mathrm{KBr}, \mathrm{cm}^{-1}\right): 2215(\mathrm{CN}), 3413\left(\mathrm{NH}_{2}\right), 1598(\mathrm{C}=\mathrm{N}$ ring); MS (EI) $\mathrm{m} / z$. 649.3 (20.3\%, M+); anal. calcd for $\mathrm{C}_{43} \mathrm{H}_{35} \mathrm{~N}_{7}$ : C: $79.33, \mathrm{H}: 5.4, \mathrm{~N}: 15.4$. Found: 79.46, H: 5.4, N: 15.09.

\subsection{Preparation of}

4-(3-Methyl-1,5-Diphenyl-1H-Pyrazol-4-yl)-8-(E)

[(3-Methyl-1,5-Diphenyl-1H-Pyrazol-4-yl) Methylene]-2-0xo1,2,5,6,7,8-Hexahydroquinoline-3-Carbonitrile (8)

Compound $4 \mathrm{a}(1.5 \mathrm{~g}, 0.01 \mathrm{~mol})$ was mixed with ethylcyanoacetate $(0.3 \mathrm{~g}, 0.1$ $\mathrm{mol}$ ) and ammonium acetate $(2 \mathrm{~g}, 0.1 \mathrm{~mol})$ in ethyl alcohol $(99 \%)(50 \mathrm{ml})$, the reaction mixture was refluxed for $15 \mathrm{~h}$. After cooling, the formed precipitate was filtered, washed with ethyl alcohol, then washed with water, dried and purified by $\mathrm{SiO}_{2}$ (preparative TLC petroleum ether: ethylacetate 3:1) to yield compound 8 as yellow powder; yield $41 \%(0.7 \mathrm{~g}) ; \mathrm{mp} 152^{\circ} \mathrm{C}-153^{\circ} \mathrm{C} .{ }^{1} \mathrm{H}$ NMR (DMSO- $\left.d_{6}\right): \delta$ $9.1\left(\mathrm{~s}, 1 \mathrm{H}, \mathrm{NH}\left(\mathrm{D}_{2} \mathrm{O}\right.\right.$ exchangeable), $7.1-7.7(\mathrm{~m}, 20 \mathrm{H}, \mathrm{Ar}-\mathrm{H}), 6.3(\mathrm{~s}, 1 \mathrm{H}$, $\mathrm{H}$-methylene), 3.3 (m, $4 \mathrm{H}$, quinoline- $\mathrm{H} 5, \mathrm{H7}), 2.1\left(\mathrm{~s}, 6 \mathrm{H}, 2 \mathrm{CH}_{3}\right), 1.9(\mathrm{~m}, 2 \mathrm{H}$, quinoline-H6); IR ( $\left.\mathrm{KBr}, \mathrm{cm}^{-1}\right)$ : $2221(\mathrm{CN}), 3400(\mathrm{NH})$; MS (EI) $\mathrm{m} / \mathrm{z} .650$ (57\%, M+); anal. calcd for $\mathrm{C}_{43} \mathrm{H}_{34} \mathrm{~N}_{7}$ : C: 79.48, H: 5.4, N: 12.78. Found: C: 79.33, H: 5.4, N: 12.91 .

\subsection{Preparation of}

2-Chloro-4-(3-Methyl-1,5-Diphenyl-1H-Pyrazol-4-yl)-8-(E)[(3 -Methyl-1,5-Diphenyl-1H-Pyrazol-4-yl) Methylene]1,2,5,6,7,8-Hexahydroquinoline-3-Carbonitrile (9)

A mixture of 8 ( $0.7 \mathrm{~g}, 0.0013 \mathrm{~mol})$, phosphorus oxychloride $(2.5 \mathrm{ml}, 0.026 \mathrm{~mol})$ and $N, N$-diethylaniline (DEA) $(0.1 \mathrm{ml})$ was heated for $6 \mathrm{~h}$. After cooling by ice $(15 \mathrm{ml})$, the product turned into filteration, dried and washed with ice-water to yield compound 9 as yellow powder; yield $71 \%(0.5 \mathrm{~g}) ; \mathrm{mp} 190^{\circ} \mathrm{C}-192^{\circ} \mathrm{C} ;{ }^{1} \mathrm{H}$ NMR (DMSO- $d_{6}$ ): $\delta 7.1-7.7$ (m, 20H, Ar-H), 6.1 (s, 1H, H-methylene), $3.3(\mathrm{~m}$, $4 \mathrm{H}$, quinoline- $\mathrm{H} 5, \mathrm{H} 7), 2.1\left(\mathrm{~s}, 6 \mathrm{H}, 2 \mathrm{CH}_{3}\right), 1.9(\mathrm{~m}, 2 \mathrm{H}$, quinoline-H6). IR $(\mathrm{KBr}$, $\left.\mathrm{cm}^{-1}\right): 2220(\mathrm{CN})$, absence of $\mathrm{C}=\mathrm{O}$ band at 1670; MS (EI) $\mathrm{m} / z .673(11 \%, \mathrm{M}++2)$, $671(20 \%, \mathrm{M}+)$; anal. calcd for $\mathrm{C}_{43} \mathrm{H}_{33} \mathrm{ClN}_{6}$ : C: $76.85, \mathrm{H}: 5.85, \mathrm{Cl}: 5.13, \mathrm{~N}: 12.46$. 
Found: C: 76.2, H: 5.11, Cl: 5.5, N: 12.2.

\subsection{Preparation of $10 a, b$}

The $\alpha, \beta$-unsaturated ketone $4 \mathrm{a}$ or $4 \mathrm{~b}(0.01 \mathrm{~mol})$ was mixed with thiourea $(0.8 \mathrm{~g}$, $0.01 \mathrm{~mol})$ and Sodium metal $(0.5 \mathrm{~g})$ in butyl alcohol $(50 \mathrm{~mL})$. The mixture was refluxed for $10 \mathrm{~h}$. The extra of solvent became concentrated in vacuo and the residue changed into $\mathrm{pH}$ 6. The separated stable turned into filteration, washed with water, dried and purified through $\mathrm{SiO}_{2}$ (preparative TLC petroleum ether: ethyl acetate 3:1).

4-(3-Methyl-1,5-diphenyl-1 $H$-pyrazol-4-yl)-8-(E) [(3-methyl-1,5-dipheny 1-1 $H$-pyrazol-4-yl)methylene]-4,4a,5,6,7,8-hexahydroquinazoline-2 $(3 H)$-thi one (10a): As yellow solid; yield $20 \%(0.3 \mathrm{~g}) ; \mathrm{mp} 138^{\circ} \mathrm{C}-140^{\circ} \mathrm{C} ;{ }^{1} \mathrm{H}$ NMR $\left(\mathrm{DMSO}-d_{6}\right): \delta 8.3(\mathrm{~s}, 1 \mathrm{H}, \mathrm{SH}), 7.1-7.3(\mathrm{~m}, 20 \mathrm{H}, 20 \mathrm{Ar}-\mathrm{H}), 5.4(\mathrm{~s}, 1 \mathrm{H}$, $\mathrm{H}$-methylene), $2.8(\mathrm{~m}, 4 \mathrm{H}$, quinazoline- $\mathrm{H} 5, \mathrm{H} 7), 2.4\left(\mathrm{~s}, 6 \mathrm{H}, 2 \mathrm{CH}_{3}\right), 1.6(\mathrm{~m}, 2 \mathrm{H}$, quinazoline-H6); MS (EI) $\mathrm{m} / \mathrm{z}$. $644(51 \%, \mathrm{M}+)$; anal. calcd for $\mathrm{C}_{41} \mathrm{H}_{34} \mathrm{~N}_{6} \mathrm{~S}$ : C: 76.37, H: 5.63, N: 13.03, S: 4.97. Found: C: 76.2, H: 5.11, N: 13.2, S: 4.5.

6-Methyl-4-(3-methyl-1,5-diphenyl-1 $H$-pyrazol-4-yl)-8-(E) [(3-methyl-1, 5-diphenyl-1 $H$-pyrazol-4-yl)methylene]-4,4a,5,6,7,8-hexahydropyrido[4,3d] pyrimidine-2(3H)-thione (10b): As brown solid; yield 15\% (0.2 g); mp $150^{\circ} \mathrm{C}-153^{\circ} \mathrm{C} ;{ }^{1} \mathrm{H}$ NMR (DMSO- $\left.d_{6}\right): \delta 9.2(\mathrm{~d}, 1 \mathrm{H}, \mathrm{SH}), 7.1-7.3(\mathrm{~m}, 20 \mathrm{H}$, 20Ar-H), 4.8 (s, 1H, H-methylene), 3.3 (s, 4H, pyridine-H2,H6), $2.4(\mathrm{~s}, 6 \mathrm{H}$, $\left.2 \mathrm{CH}_{3}\right), 2.2\left(\mathrm{~s}, 3 \mathrm{H}, \mathrm{N}-\mathrm{CH}_{3}\right)$; MS (EI) $\mathrm{m} / \mathrm{z} .659 .1(5.5 \%, \mathrm{M}+)$; anal. calcd for $\mathrm{C}_{41} \mathrm{H}_{35} \mathrm{~N}_{7} \mathrm{~S}: \mathrm{C}: 74.63, \mathrm{H}: 5.65, \mathrm{~N}: 14.86 ; \mathrm{S}: 4.86$. Found: C: $74.2, \mathrm{H}: 5.55, \mathrm{~N}: 14.2, \mathrm{~S}$ : 4.67 .

\subsection{Preparation of $11 a, b$}

A solution of 2 -aminothiazole $(0.08 \mathrm{~g}, 0.01 \mathrm{~mol})$ and the $\alpha, \beta$-unsaturated ketone $4 \mathrm{a}$ or $4 \mathrm{~b}(0.5 \mathrm{~g}, 0.01 \mathrm{~mol})$ in glacial ethanoic acid $(20 \mathrm{ml})$ was refluxed for $20 \mathrm{~h}$. Solvent was dried under reduced pressure; then washed with water. The obtained product was recrystallized from ethyl alcohol.

5-(3-Methyl-1,5-diphenyl-1 $H$-pyrazol-4-yl)-9-( $E$ ) [(3-methyl-1,5-dipheny 1-1 $H$-pyrazol-4-yl)methylene]-6,7,8,9-tetrahydro-5 $H$-thiazolo[2,3- $b$ ]quinaz oline (11a): As yellow crystals; yield $80 \%(0.4 \mathrm{~g}) ; \mathrm{mp} 200^{\circ} \mathrm{C}-201{ }^{\circ} \mathrm{C} ;{ }^{1} \mathrm{H}$ NMR $\left(\right.$ DMSO- $\left.d_{6}\right): \delta 7.1-7.3(\mathrm{~m}, 22 \mathrm{H}, 20 \mathrm{Ar}-\mathrm{H}$ and 2 Thiazole-H), $6.3(\mathrm{~s}, 1 \mathrm{H}$, $\mathrm{H}$-methylene), $4.5(\mathrm{~s}, 1 \mathrm{H}$, thiazolo quinazoline- $\mathrm{H} 5), 2.8(\mathrm{~m}, 2 \mathrm{H}$, thiazolo quinazoline-H8), $2.5\left(\mathrm{~s}, 6 \mathrm{H}, 2 \mathrm{CH}_{3}\right), 1.6(\mathrm{~m}, 4 \mathrm{H}$, thiazolo quinazoline-H6, H7). ${ }^{13} \mathrm{CNMR}$ : $\delta 13$ (1c), 14 (1c), 23.3 (1c), 23.2 (1c), 25 (1c), 56 (1c), 97 (1c), 113 (1c), 119 (1c), 124 (1c), 124.5 (4c), 126.4 (2c), 127.5 (4c), 128.8 (2c), 129.9 (8c), 132 (2c), 133 (3c), 134.1 (1c), 139.2 (2c), 142 (1c), 146 (1c), 148.7 (1c), 150 (1c), 152.9 (1c), 158.4 (1c); MS (EI) $\mathrm{m} / z$. $668(13 \%, \mathrm{M}+)$; anal. calcd for $\mathrm{C}_{43} \mathrm{H}_{36} \mathrm{~N}_{6} \mathrm{~S}$ : C: 77.22 , H: 5.43, N: 12.56, S: 4.79. Found: C: 77.20, H: 5.81, N: 12.40, S: 4.91.

7-Methyl-5-(3-methyl-1,5-diphenyl-1 $H$-pyrazol-4-yl)-9-(E) [(3-methyl-1, 5-diphenyl-1 $H$-pyzol-4-yl)methylene]-6,7,8,9-tetrahydro-5 $H$-pyrido[4,3-d]t 
hiazolo[3,2-a]pyrimidine (11b): As brown crystals; yield 80\% (0.4 g); mp $130^{\circ} \mathrm{C}-133^{\circ} \mathrm{C} ;{ }^{1} \mathrm{H}$ NMR (DMSO- $d_{6}$ ): $\delta 7.1-7.3$ (m, 22H, 20Ar-H and 2Thiazole-H), 6.3 (s, $1 \mathrm{H}, \mathrm{H}$-methylene), 4.5 (s, $1 \mathrm{H}$, pyrimidine- $\mathrm{H} 4), 3.1(\mathrm{~m}, 4 \mathrm{H}$, pyridine $\mathrm{H} 2, \mathrm{H} 6), 2.4\left(\mathrm{~s}, 6 \mathrm{H}, \mathrm{CH}_{3}\right), 2.2\left(\mathrm{~s}, 3 \mathrm{H}, \mathrm{N}-\mathrm{CH}_{3}\right)$; IR $\left(\mathrm{KBr}, \mathrm{cm}^{-1}\right): 1529$ (C=N ring); MS (EI) m/z: 683.1 (5\%, M+; anal. calcd for $\mathrm{C}_{43} \mathrm{H}_{37} \mathrm{~N}_{7} \mathrm{~S}$ : C: $75.52, \mathrm{H}$ : 5.45, N: 14.34, S: 4.69. Found: C: 75.22, H: 5.82, N :14.40, S: 4.95.

\subsection{Preparation of $12 a, b$ and 13}

A mixture of compound 3 ( $2 \mathrm{~g}, 0.1 \mathrm{~mol})$ and appropriate aromatic amine in glacial ethanoic acid $(20 \mathrm{ml})$ was heated under reflux for $5 \mathrm{~h}$. The solid was precipitated by adding cold water. The separated solid turned into filteration, washed with water, dried and purified by means of $\mathrm{SiO}_{2}$ (preparative TLC petroleum ether: ethyl acetate 3:1).

[1-(3-Methyl-1,5-diphenyl-1 $H$-pyrazol-4-yl)]- $N$-phenylmethanimine

(12a): aniline $(0.8 \mathrm{~g}, 0.1 \mathrm{~mol})$ to yield pure white powder; yield $38 \%(1 \mathrm{~g}) ; \mathrm{mp}$ $120^{\circ} \mathrm{C}-122^{\circ} \mathrm{C} ;{ }^{1} \mathrm{H}$ NMR (DMSO- $\left.d_{6}\right): \delta 8.1(\mathrm{~s}, 1 \mathrm{H}, \mathrm{CH}=\mathrm{N}), 7.2-7.4(\mathrm{~m}, 15 \mathrm{H}$, Ar-H), 2.6 (s, 3H, $\mathrm{CH}_{3}$-pyrazole); ${ }^{13} \mathrm{C}$ NMR: $\delta 14.3$ (1c), 116.9 (1c), 120.5 (2c), 125 (2c), 125.2 (1c), 127.6 (1c), 128.1 (1c), 128.7 (2c), 128.9 (2c), 129.1 (2c), 129.2 (2c), 130.2 (1c), 138.8 (1c), 145.7 (1c), 148.7 (1c), 152.7 (1c), 153.5 (1c); MS (EI) $\mathrm{m} / \mathrm{z}$. 337.1 (40.4\%, M+); anal. calcd for $\mathrm{C}_{23} \mathrm{H}_{19} \mathrm{~N}_{3}$ : C: 81.87; H, 5.68; N, 12.45 . Found: C: $81.45, \mathrm{H}: 5.81, \mathrm{~N}: 12.74$.

[1-(3-Methyl-1,5-diphenyl-1 $H$-pyrazol-4-yl)- $N$-(3-methylphenyl)]metha nimine (12b): $m$-toluidine $(0.7 \mathrm{~g}, 0.1 \mathrm{~mol})$ to yield brown powder; yield $40 \%(1$ g); $\mathrm{mp} 120^{\circ} \mathrm{C}-122^{\circ} \mathrm{C} ;{ }^{1} \mathrm{H}$ NMR (DMSO- $\left.d_{6}\right): \delta 8.1(\mathrm{~s}, 1 \mathrm{H}, \mathrm{CH}=\mathrm{N}), 7.2-7.4(\mathrm{~m}$, 14H, Ar-H), 2.4 (s, 3H, CH ${ }_{3}$-pyrazole), 2.2 (s, 3H, $\mathrm{CH}_{3}$ ); MS (EI) m/z. 351.1 (38.7\%, M+); anal. calcd for $\mathrm{C}_{24} \mathrm{H}_{21} \mathrm{~N}_{3}$ : C: 82.02; H:6.02; N: 11.96. Found: C: 82.45, H: 6.81, N: 11.74 .

[1-(3-Methyl-1,5-diphenyl-1 $H$-pyrazol-4-yl)- $\mathrm{N}$-(thiazol-2-yl)]methanimi ne (13): 2-aminothiazole $(0.7 \mathrm{~g}, 0.1 \mathrm{~mol})$ to yield buff powder; $62 \%(1.5 \mathrm{~g}) ; \mathrm{mp}$ $130^{\circ} \mathrm{C}-131.5^{\circ} \mathrm{C} ;{ }^{1} \mathrm{H}$ NMR (DMSO- $\left.d_{6}\right): \delta 8.1(\mathrm{~s}, 1 \mathrm{H}, \mathrm{CH}=\mathrm{N}), 7.1-7.8(\mathrm{~m}, 12 \mathrm{H}$, Ar-H), 2.5 (s, $3 \mathrm{H}, \mathrm{CH}_{3}$-pyrazole). anal. calcd for $\mathrm{C}_{20} \mathrm{H}_{16} \mathrm{~N}_{4} \mathrm{~S}: \mathrm{C}: 69.74 ; \mathrm{H}: 4.68 ; \mathrm{N}$ : 16.27, S: 9.31. Found: C: 69.43, H: 4.81, N: 16.74, S: 9.22.

\subsection{Preparation of [2-(3-Methyl-1,5-Diphenyl-1H-Pyrazol-4-yl) Methylene] Malononitrile (14)}

Mixture of methyl-1, 5-diphenyl-1H-pyrazole-4-carbaldehyde 3 (3.5 g, $1 \mathrm{~mol}$ ), malononitrile $(0.9 \mathrm{~g}, 1 \mathrm{~mol})$, in ethyl alcohol 95\% (20 ml) were refluxed for $12 \mathrm{~h}$. After of entirety of the reaction with the aid of TLC, the mixture changed into cooling to $25^{\circ} \mathrm{C}$, filtered and washed with water. The resulting solid product was recrystallized from methanol to yield compound 14 as pure yellow crystals $75 \%$ (3 g); mp $135^{\circ} \mathrm{C}-136^{\circ} \mathrm{C} ;{ }^{1} \mathrm{H}$ NMR (DMSO- $d_{6}$ ): $\delta 8.1$ (s, $1 \mathrm{H}$, ethylenic-H), $7.4(\mathrm{~d}$, $3 \mathrm{H}, J=5 \mathrm{~Hz}, \mathrm{Ar}-\mathrm{H}), 7.3$ (s, 3H, Ar-H), 7.2 (d, $4 \mathrm{H}, J=5 \mathrm{~Hz}, \mathrm{Ar}-\mathrm{H}), 2.5$ (d, 3H, $J$ $\left.=5 \mathrm{~Hz}, \mathrm{CH}_{3}\right){ }^{13} \mathrm{C}$ NMR: $\delta 14.2$ (1c), 80.7 (1c), 113.3 (1c), $114.2(1 \mathrm{c}), 114.6(1 \mathrm{c})$, 
125.3 (2c), 127.5 (1c), 128.5 (1c), 129 (1c), 129.1(1c), 129.8 (1c), 129.9 (2c), 138.3 (2c), 146.1 (1c), 149.1 (2c), 154.3 (1c); IR (KBr, cm $\left.{ }^{-1}\right): 2221$ (CN), 1597 (C=C, $\mathrm{C}=\mathrm{N}$ of ring); $\mathrm{MS}(\mathrm{EI}) \mathrm{m} / z$ : $310.1(100 \%, \mathrm{M}+)$; anal. calcd for $\mathrm{C}_{20} \mathrm{H}_{14} \mathrm{~N}_{4}: \mathrm{C}: 77.40$; $\mathrm{H}: 4.55$; N: 18.05. Found: C: 77.43, H: 4.81, N: 18.43 .

\subsection{Preparation of 15,16}

Mixture of compound 14 (3.5 g, $1 \mathrm{mmol})$, the appropriate naphthol $(1 \mathrm{mmol})$ and methanesulfonic acid $(1.2 \mathrm{~g}, 1 \mathrm{mmol})$ in acetonitrile $(5 \mathrm{ml})$ were refluxed for $5 \mathrm{~h}$. After completion of the reaction, the aggregate turned into cooling to room temperature and filtered. The filtrate wad washed by $5 \% \mathrm{NaHCO}_{3}$ and dried over $\mathrm{MgSO}_{4}$. The solvent turned into evaporated. The resulting solid product turned into recrystallization from methyl alcohol.

[2-Amino-4-(3-methyl-1,5-diphenyl-1 $H$-pyrazol-4-yl)]-4 $H$-benzo[ $h]$ chro mene-3-carbonitrile (15): Pure white crystals; yield 50\% (3 g); mp $120^{\circ} \mathrm{C}$ $121^{\circ} \mathrm{C} .{ }^{1} \mathrm{H}$ NMR (DMSO- $\left.d_{6}\right): \delta 7.2-7.4(\mathrm{~m}, 16 \mathrm{H}, \mathrm{Ar}-\mathrm{H}), 6.9\left(\mathrm{~s}, 2 \mathrm{H}, \mathrm{NH}_{2}\left(\mathrm{D}_{2} \mathrm{O}\right.\right.$ exchangeable), 4.7 (s, $1 \mathrm{H}$, benzochromene-H4), $1.7\left(\mathrm{~s}, 3 \mathrm{H}, \mathrm{CH}_{3}\right) ; \mathrm{IR}\left(\mathrm{KBr}, \mathrm{cm}^{-1}\right)$ : $2188(\mathrm{CN}), 3448\left(\mathrm{NH}_{2}\right)$; anal.cald for $\mathrm{C}_{30} \mathrm{H}_{22} \mathrm{~N}_{4}: \mathrm{C}: 79.27 ; \mathrm{H}:$ s4.88; N: 12.33 . Found: C: $79.6 ; \mathrm{H}: 4.5 ; \mathrm{N}: 12.8$.

[2-Amino-4-(3-methyl-1,5-diphenyl-1 $H$-pyrazol-4-yl)]-4 $H$-benzo[ $g]$ chro mene-3-carbonitrile (16): To give pure white crystals; yield 40\% (2 g); mp $150^{\circ} \mathrm{C}-151^{\circ} \mathrm{C} .{ }^{1} \mathrm{H}$ NMR (DMSO- $\left.d_{6}\right): \delta 9.7$ (s, 2H, $\mathrm{NH}_{2}\left(\mathrm{D}_{2} \mathrm{O}\right.$ exchangeable), 7.1 - 7.7 (m, 16H, Ar-H), 3.3 (s, 1H, H-4benzochromene), 2.5 (s, 3H, $\mathrm{CH}_{3}$ ); IR ( $\mathrm{KBr}$, $\mathrm{cm}^{-1}$ ): $2188(\mathrm{CN}), 3448\left(\mathrm{NH}_{2}\right)$; MS (EI) $\mathrm{m} / \mathrm{z} .454 .3$ (10.5\%, M+); anal. calcd for $\mathrm{C}_{30} \mathrm{H}_{22} \mathrm{~N}_{4}:$ C: $79.27, \mathrm{H}: 4.88, \mathrm{~N}: 12.33$. Found: C: $79.43, \mathrm{H}: 4.81, \mathrm{~N}: 12.74$.

\subsection{Preparation of 17}

A solution of compound 16 (4.6 g, $2 \mathrm{~mol}$ ) in $15 \mathrm{ml}$ of ethanol was added to $80 \%$ hydrazine hydrate $(0.6 \mathrm{ml}, 1 \mathrm{~mol})$. The mixture was stirred at $25^{\circ} \mathrm{C}$ for $4 \mathrm{hrs}$, the solvent was evaporated under reduced pressure. The residue was washed with ethyl alcohol, recrystallized from the water.

[5-Amino-3'-methyl-1',5'-diphenyl-1 $H, 1^{\prime} H$-3,4'-bipyrazole]-4-carbonitril e (17): As white needles; yield $40 \%$ (1 g); mp $197^{\circ} \mathrm{C}-198^{\circ} \mathrm{C} ;{ }^{1} \mathrm{H}$ NMR (DMSO- $\left.d_{6}\right): \delta 7.5\left(\mathrm{~s}, 1 \mathrm{H}, \mathrm{NH}\left(\mathrm{D}_{2} \mathrm{O}\right.\right.$ exchangeable), $7.1-7.4(\mathrm{~m}, 10 \mathrm{H}, \mathrm{Ar}-\mathrm{H}), 6.4$ (s, $2 \mathrm{H}, \mathrm{NH}_{2}\left(\mathrm{D}_{2} \mathrm{O}\right.$ exchangeable), $2.5\left(\mathrm{~d}, 3 \mathrm{H}, J=5 \mathrm{~Hz}, \mathrm{CH}_{3}\right) ; \mathrm{IR}\left(\mathrm{KBr}, \mathrm{cm}^{-1}\right): 2200$ (CN), $3420\left(\mathrm{NH}_{2}\right)$; MS (EI) $\mathrm{m} / z$ : 340 (13.3\%, M+); anal. calcd for $\mathrm{C}_{20} \mathrm{H}_{16} \mathrm{~N}_{6}$ : C: 70.57, H: 4.74, N: 24.69. Found: C: 70.43, H: 4.25, N: 24.74.

\section{Conclusion}

A series of new compounds have been synthesized using efficient methods and tested for their biological activities. There is a strong correlation between molecular modeling and biological screening results which suppose that the structural modification of the lead structure affects the activity in a predictable manner; as shown in (Figures 2-6), CA-4 shows highest binding affinity with its methoxy 
phenyl moiety and $2 \mathrm{C}$ bridge. Compound $5 \mathrm{~b}$ with $6 \mathrm{C}$ bridge and the methoxy phenyl moiety is replaced by diphenyl pyrazole ring gives good binding with colchicine binding site. Compounds 15 and 16 with a $4 \mathrm{C}$ spacer as double bond is replaced by chromene, ring $\mathrm{A}$ is replaced by diphenyl pyrazole moiety and ring $B$ is replaced by naphthalene, have a good binding affinity with the protein but compound 15 have the best binding affinity. In compound 17, after removing $2 \mathrm{C}$ distance, replacing ring $\mathrm{A}$ and $\mathrm{B}$ by substituted pyrazoles, we found that the activity as tubulin inhibitor highly increased and it's been considered as strong colchicine binding site agent.

\section{Acknowledgements}

Authors wish to thank Faculty of pharmacy, Mansoura University and Delta University for science and Technology for funding and using their laboratories equipment. Thanks for National Cancer Institute, Cairo, Egypt.

\section{References}

[1] Zhou, J. and Giannakakou, P. (2005) Targeting Microtubules for Cancer Chemotherapy. Current Medicinal Chemistry Anti-Cancer Agents, 5, 65-71. https://doi.org/10.2174/1568011053352569

[2] Perez, E.A. (2009) Microtubule Inhibitors: Differentiating Tubulin-Inhibiting Agents Based on Mechanisms of Action, Clinical Activity, and Resistance. Molecular Cancer Therapeutics, 8, 2086-2095. https://doi.org/10.1158/1535-7163.MCT-09-0366

[3] Prota, A.E., Bargsten, K., Zurwerra, D., Field, J.J., Diaz, J.F., Altmann, K.H. and Steinmetz, M.O. (2013) Molecular Mechanism of Action of Microtubule-Stabilizing Anticancer Agents. Science (New York, NY), 339, 587-590. https://doi.org/10.1126/science.1230582

[4] Liu, Y.M., Chen, H.L., Lee, H.Y. and Liou, J.P. (2014) Tubulin Inhibitors: A Patent Review. Expert Opinion on Therapeutic Patents, 24, 69-88. https://doi.org/10.1517/13543776.2014.859247

[5] Mohamed, S.S., Tamer, A.R., Bensaber, S.M., Jaeda, M.I., Ermeli, N.B., Allafi, A.A., Mrema, I.A., Erhuma, M., Hermann, A. and Gbaj, A.M. (2013) Design, Synthesis, Molecular Modeling, and Biological Evaluation of Sulfanilamide-Imines Derivatives as Potential Anticancer Agents. Naunyn-Schmiedeberg's Archives of Pharmacology, 386, 813-822. https://doi.org/10.1007/s00210-013-0883-y

[6] Hu, Y., Lu, X., Chen, K., Yan, R., Li, Q.S. and Zhu, H.L. (2012) Design, Synthesis, Biological Evaluation and Molecular Modeling of 1,3,4-Oxadiazoline Analogs of Combretastatin-A4 as Novel Antitubulin Agents. Bioorganic \& Medicinal Chemistry, 20, 903-909. https://doi.org/10.1016/j.bmc.2011.11.057

[7] Ducki, S., Forrest, R., Hadfield, J.A., Kendall, A., Lawrence, N.J., McGown, A.T. and Rennison, D. (1998) Potent Antimitotic and Cell Growth Inhibitory Properties of Substituted Chalcones. Bioorganic \& Medicinal Chemistry Letters, 8, 1051-1056. https://doi.org/10.1016/S0960-894X(98)00162-0

[8] Tron, G.C., Pagliai, F., Del Grosso, E., Genazzani, A.A. and Sorba, G. (2005) Synthesis and Cytotoxic Evaluation of Combretafurazans. Journal of Medicinal Chemistry, 48, 3260-3268. https://doi.org/10.1021/jm049096o 
[9] Wang, L., Woods, K.W., Li, Q., Barr, K.J., McCroskey, R.W., Hannick, S.M., Gherke, L., Cre-do, R.B., Hui, Y.H., Marsh, K., Warner, R., Lee, J.Y., Zielinski-Mozng, N., Frost, D., Rosenberg, S.H. and Sham, H.L. (2002) Potent, Orally Active Heterocycle-Based Combretastatin A-4 Analogues: Synthesis, Structure-Activity Relationship, Pharmacokinetics, and In Vivo Antitumor Activity Evaluation. Journal of Medicinal Chemistry, 45, 1697-1711. https://doi.org/10.1021/jm010523x

[10] Bailly, C., Bal, C., Barbier, P., Combes, S., Finet, J.P., Hildebrand, M.P., Peyrot, V. and Wattez, N. (2003) Synthesis and Biological Evaluation of 4-Arylcoumarin Analogues of Combretastatins. Journal of Medicinal Chemistry, 46, 5437-5444. https://doi.org/10.1021/jm030903d

[11] Nam, N.-H., Kim, Y., You, Y.-J., Hong, D.-H., Kim, H.-M. and Ahn, B.-Z. (2001) Combretoxazolones: Synthesis, Cytotoxicity and Antitumor Activity. Bioorganic \& Medicinal Chemistry Letters, 11, 3073-3076. https://doi.org/10.1016/S0960-894X(01)00622-9

[12] Kim, Y., Nam, N.H., You, Y.J. and Ahn, B.Z. (2002) Synthesis and Cytotoxicity of 3,4-Diaryl-2(5H)-Furanones. Bioorganic \& Medicinal Chemistry Letters, 12, 719-722. https://doi.org/10.1016/S0960-894X(01)00831-9

[13] Nam, N.H., Kim, Y., You, Y.J., Hong, D.H., Kim, H.M. and Ahn, B.Z. (2002) Synthesis and Anti-Tumor Activity of Novel Combretastatins: Combretocyclopentenones and Related Analogues. Bioorganic \& Medicinal Chemistry Letters, 12, 1955-1958. https://doi.org/10.1016/S0960-894X(02)00321-9

[14] Simoni, D., Grisolia, G., Giannini, G., Roberti, M., Rondanin, R., Piccagli, L., Baruchello, R., Rossi, M., Romagnoli, R., Invidiata, F.P., Grimaudo, S., Jung, M.K., Hamel, E., Gebbia, N., Crosta, L., Abbadessa, V., Di Cristina, A., Dusonchet, L., Meli, M. and Tolomeo, M. (2005) Heterocyclic and Phenyl Double-Bond-Locked Combretastatin Analogues Possessing Potent Apopto-Sis-Inducing Activity in HL60 And in MDR Cell Lines. Journal of Medicinal Chemistry, 48, 723-736. https://doi.org/10.1021/jm049622b

[15] Flynn, B.L., Flynn, G.P., Hamel, E. and Jung, M.K. (2001) The Synthesis and Tubulin Binding Activity of Thiophene-Based Analogues of Combretastatin A-4. Bioorganic \& Medicinal Chemistry Letters, 11, 2341-2343. https://doi.org/10.1016/S0960-894X(01)00436-X

[16] Genin, M.J., Biles, C., Keiser, B.J., Poppe, S.M., Swaney, S.M., Tarpley, W.G., Yagi, Y. and Romero, D.L. (2000) Novel 1,5-Diphenylpyrazole Nonnucleoside HIV-1 Reverse Transcriptase Inhibitors with Enhanced Activity versus the Delavirdine-Resistant P236L Mutant: Lead Identification and SAR of 3- and 4-Substituted Derivatives. Journal of Medicinal Chemistry, 43, 1034-1040. https://doi.org/10.1021/jm990383f

[17] Patil, C.B., Mahajan, S.K. and Katti, S.A. (2009) Chalcone: A Versatile Molecule. Journal of Pharmaceutical Sciences and Research, 1, 11-22.

[18] Al-Omary, F.A., Hassan, G.S., El-Messery, S.M. and El-Subbagh, H.I. (2012) Substituted Thiazoles V. Synthesis and Antitumor Activity of Novel Thiazolo[2,3-B] Quinazoline and Pyri-Do[4,3-D]Thiazolo[3,2-A]Pyrimidine Analogues. European Journal of Medicinal Chemistry, 47, 65-72. https://doi.org/10.1016/j.ejmech.2011.10.023

[19] Dimmock, J.R., Kumar, P., Nazarali, A.J., Motaganahalli, N.L., Kowalchuk, T.P., Beazely, M.A., Wilson Quail, J., Oloo, E.O., Allen, T.M., Szydlowski, J., DeClercq, E. and Balzarini, J. (2000) Cytotoxic 2,6-Bis(Arylidene)Cyclohexanones and Related Compounds. European Journal of Medicinal Chemistry, 35, 967-977. 
https://doi.org/10.1016/S0223-5234(00)01173-9

[20] Dimmock, J.R., Padmanilayam, M.P., Zello, G.A., Nienaber, K.H., Allen, T.M., Santos, C.L., De Clercq, E., Balzarini, J., Manavathu, E.K. and Stables, J.P. (2003) Cytotoxic Analogues of 2,6-Bis(Arylidene)Cyclohexanones. European Journal of Medicinal Chemistry, 38, 169-177. https://doi.org/10.1016/S0223-5234(02)01444-7

[21] El-Subbagh, H.I., Abu-Zaid, S.M., Mahran, M.A., Badria, F.A. and Al-Obaid, A.M. (2000) Synthesis and Biological Evaluation of Certain Alpha, Beta-Unsaturated Ketones and Their Corresponding Fused Pyridines as Antiviral and Cytotoxic Agents. Journal of Medicinal Chemistry, 43, 2915-2921. https://doi.org/10.1021/jm000038m

[22] Rostom, S.A., Hassan, G.S. and El-Subbagh, H.I. (2009) Synthesis and Biological Evaluation of Some Polymethoxylated Fused Pyridine Ring Systems as Antitumor Agents. Archiv der Pharmazie, 342, 584-590. https://doi.org/10.1002/ardp.200900062

[23] Safaei-Ghomi, J., Bamoniri, A.H. and Soltanian-Telkabadi, M. (2006) A Modified and Convenient Method for the Preparation of N-Phenylpyrazoline Derivatives. Chemistry of Heterocyclic Compounds, 42, 892-896. https://doi.org/10.1007/s10593-006-0176-1

[24] Da Silva, C.M., da Silva, D.L., Modolo, L.V., Alves, R.B., de Resende, M.A., Martins, C.V.B. and de Fátima, Â. (2011) Schiff Bases: A Short Review of Their Antimicrobial Activities. Journal of Advanced Research, 2, 1-8. https://doi.org/10.1016/j.jare.2010.05.004

[25] Gupta, R., Fuloria, N.K. and Fuloria, S. (2013) Synthesis and Antimicrobial Activity Evaluation of Some Schiff Bases Derived from 2-Aminothiazole Derivatives. Indonesian Journal of Pharmacyl Majalah Farmasi Indonesia, 24, 35-39.

[26] Heravi, M.M., Baghernejad, B. and Oskooie, H.A. (2008) A Novel and Efficient Catalyst to One-Pot Synthesis of 2-Amino-4H-Chromenes by Methanesulfonic Acid. Journal of the Chinese Chemical Society, 55, 659-662. https://doi.org/10.1002/jccs.200800098

[27] Mosmann, T. (1983) Rapid Colorimetric Assay for Cellular Growth and Survival: Application to Proliferation and Cytotoxicity Assays. Journal of Immunological Methods, 65, 55-63. https://doi.org/10.1016/0022-1759(83)90303-4

[28] Denizot, F. and Lang, R. (1986) Rapid Colorimetric Assay for Cell Growth and Survival. Modifications to the Tetrazolium Dye Procedure Giving Improved Sensitivity and Reliability. Journal of Immunological Methods, 89, 271-277.

https://doi.org/10.1016/0022-1759(86)90368-6

[29] Mauceri, H.J., Hanna, N.N., Beckett, M.A., Gorski, D.H., Staba, M.J., Stellato, K.A., Bigelow, K., Heimann, R., Gately, S., Dhanabal, M., Soff, G.A., Sukhatme, V.P., Kufe, D.W. and Weichselbaum, R.R. (1998) Combined Effects of Angiostatin and Ionizing Radiation in Antitumour Therapy. Nature, 394, 287-291. https://doi.org/10.1038/28412

[30] Lowe, J., Li, H., Downing, K.H. and Nogales, E. (2001) Refined Structure of Alpha Beta-Tubulin at 3.5 a Resolution. Journal of Molecular Biology, 313, 1045-1057. https://doi.org/10.1006/jmbi.2001.5077

[31] Ravelli, R.B., Gigant, B., Curmi, P.A., Jourdain, I., Lachkar, S., Sobel, A. and Knossow, M. (2004) In-Sight into Tubulin Regulation from a Complex with Colchicine and a Stathmin-Like Domain. Nature, 428, 198-202.

https://doi.org/10.1038/nature02393

[32] https://www.pdb.org 
[33] Hollick, J.J., Golding, B.T., Hardcastle, I.R., Martin, N., Richardson, C., Rigoreau, L.J., Smith, G.C. and Griffin, R.J. (2003) 2,6-Disubstituted Pyran-4-One and Thiopyran-4-One Inhibitors of DNA-Dependent Protein Kinase (DNA-PK). Bioorganic \& Medicinal Chemistry Letters, 13, 3083-3086.

https://doi.org/10.1016/S0960-894X(03)00652-8 